IZA DP No. 8117

Divorcing Upon Retirement:

A Regression Discontinuity Study

Elena Stancanelli

April 2014 


\title{
Divorcing Upon Retirement: A Regression Discontinuity Study
}

\author{
Elena Stancanelli \\ Paris School of Economics CNRS, \\ Sorbonne Economics Research Center and IZA
}
Discussion Paper No. 8117
April 2014

\author{
IZA \\ P.O. Box 7240 \\ 53072 Bonn \\ Germany
}

Phone: +49-228-3894-0

Fax: +49-228-3894-180

E-mail: iza@iza.org

Any opinions expressed here are those of the author(s) and not those of IZA. Research published in this series may include views on policy, but the institute itself takes no institutional policy positions. The IZA research network is committed to the IZA Guiding Principles of Research Integrity.

The Institute for the Study of Labor (IZA) in Bonn is a local and virtual international research center and a place of communication between science, politics and business. IZA is an independent nonprofit organization supported by Deutsche Post Foundation. The center is associated with the University of Bonn and offers a stimulating research environment through its international network, workshops and conferences, data service, project support, research visits and doctoral program. IZA engages in (i) original and internationally competitive research in all fields of labor economics, (ii) development of policy concepts, and (iii) dissemination of research results and concepts to the interested public.

IZA Discussion Papers often represent preliminary work and are circulated to encourage discussion. Citation of such a paper should account for its provisional character. A revised version may be available directly from the author. 


\section{ABSTRACT}

\section{Divorcing Upon Retirement: A Regression Discontinuity Study}

The many facets of retirement have been studied widely by economists. However, the effect of retirement on marriage stability has been ignored in the literature. Retirement represents a dramatic change in individual time allocation that may affect marriage stability. In particular, individuals that grew up in traditional households in which the father did little domestic work and both spouses worked very long hours such as farmer household may find their marriage especially proven by the transition into retirement. We study the effect of retirement on marriage outburst rates using observations on over 200000 French men and over 166000 French women aged 50 to 70, drawn from the French Labor Force Surveys over the period 1990 to 2002. Due to reverse causality concerns, we instrument retirement in our divorce model by exploiting legal retirement age in France and applying a regression discontinuity approach. We find a significant increase in divorce rates which soar and almost double upon retirement for individuals of either gender that grew up in a traditional family environment such as a farmer household.

JEL Classification: J14, C1, C36

Keywords: $\quad$ ageing, retirement, regression discontinuity

Corresponding author:

Elena Stancanelli

Paris School of Economics CNRS

Maison des Sciences Economiques

106-112 Boulevard de l'Hopital

75013 Paris

France

E-mail: elena.stancanelli@univ-paris1.fr

\footnotetext{
* I am grateful for discussions and helpful advice to Robert A Pollak. Earlier versions of this paper were presented at the 2014 annual Amsterdam meeting of the Network for Studies on Pension and Retirement, the May 2014 annual conference of the Society of Labor Economists in Washington DC, and at invited seminars at Irvine UC, University of South California, Santa Barbara UC, and the Paris Economic Demography seminar. I am indebted to the participants for many great and helpful suggestions. In particular, I am grateful for comments to Rob Alessie, Marco Angrisani, Marianne Bitler, Carole Bonnet, Francois Bourguignon, Maria Casanova, Damon Clark, Gerard Cornilleau, Yingying Dong, Lorena Ferraz Gonçalves, Titus Galama, Arie Kapteyn, Anne Laferrere, Shelly Lundberg, Erik Meijer, Bruce Meyer, Ruud Muffels, David Neumark, Peter Rupert, Eva Sierminska, Arthur van Soest, Anne Solaz, Gregory Verdugo and Gema Zamarro. My children also deserve special thanks for their patience and support. The research in this paper was financially supported by a research grant from the Network for Studies on Pension Aging and Retirement (Netspar). All errors are mine.
} 


\section{Introduction}

Since the pioneering work of Gary Becker, the instability of marriage has been the subject of numerous studies by economists. The well-being and health effects of retirement have also been widely researched. However, to date the relation between the individual retirement decision and marriage stability has been neglected in the economic literature. Here we argue that retirement represents a dramatic change in individual life that may also affect marriage stability. Since the quality of marriage may in turn affect individual productivity and the timing of retirement, to disentangle the direction of causality we exploit legal retirement age in France and use a regression discontinuity approach to study the effect of individual retirement on the probability to divorce.

The economic literature on divorce dates back to the pioneering work of Gary Becker. According to Gary Becker, Elisabeth Landes and Robert Michael (1977), marriage instability may result from a change in the expected returns from marriage or in their variance, the latter capturing the possible uncertainty surrounding the returns from marriage. In line with this prediction, for example, Bruce Meyer and Wallace (2013) find descriptive evidence of a negative effect of disability on marriage stability in the United States (2013). Retirement being entirely anticipated, one would not expect any effect of retirement on marriage outburst rates. Upon retirement though, traditional gender roles and gender stereotypes are likely to be challenged. ${ }^{1}$ In particular, it is found that the amount of house work performed by men increases significantly at retirement (Aguiar and Hurst, 2005 and 2007, and Stancanelli and Van Soest, 2012) and this may lead spouses to renegotiate the household allocation of time. Gopi Shah Goda, John B. Shoven, Sita Nataraj Slavov, 2007, investigated the effect of social security on divorce in the USA to conclude that spousal pension benefits do not affect the individual decision to divorce. There are no spousal pension benefits in France. Child custody laws are also likely to be of little relevance to the older population under study in this paper since children are likely to be grown up by the time individuals retire. Because earlier literature suggests that the wife is often the one that initiates the divorce even when she loses financially from the divorce (see Margaret Brining and Douglas Allen, 2000), she may be even more likely to do so if loosing survivor pension benefits is not at stake and children are already grown up and have left home. By the time individuals retire, children that often hold couples together (see, for example, Bellido et al. 2014) are likely to have left home and this may contribute to make marriages more vulnerable. In particular, since individuals plan for

\footnotetext{
${ }^{1}$ See also Akerlof and Krant (2000) on male gender identity.
} 
their retirement well in advance, to comply with standard advance notice requirements to employers and social security offices, the prospects of retirement may upset marriage stability well before the actual retirement takes place. The actual time of retirement may simply be the last drop that spills over the (marriage) cup. This is the first economic study that attempts to pin down the effect of retirement on marriage stability. ${ }^{2}$

Increases in divorces and remarriages at older ages had been documented in earlier studies (see, for example, Betsey Stevenson and Justin Wolfers, 2007). In line with this, Chart 1 based on administrative data on divorcees (collected by the French Ministry of Justice) illustrates large increases in the proportion of divorces since the nineties, for older generations in France, before and past legal retirement age ${ }^{3}$-which was sixty years for most workers at the time of our data. There are notable spikes in divorce rates both after the introduction of consensual divorce (1975) and the recent reform (2004) that eased further divorce procedures in France. Administrative data on marriage break up rates by the duration of the marriage (see Chart 2, data collected by the French Ministry of Justice) show a steady and steep increase in the proportion of marriages that end up in divorce after having lasted for 30-34 years. By the end of the nineties, as many marriages broke up after 30-34 years of duration as after the first five years of marriage (see Chart 2). Because individuals marry on average in their late twenties/early thirties and retire in their sixties, this suggests that retirement years are likely to be increasingly critical for marriage stability. In particular, because married women's employment rates have steadily increased over the last decades, and the timing of retirement is strictly regulated in France, the husband may retire while the wife is still at work and this may lead to tensions within the household, especially in more traditional couples in which the wife still does most of the housework even when she is employed. Incidentally, anecdotal evidence for Japan indicates that over 60 per cent of older women aged 60 and above are affected by a so-called 'retired husband syndrome", with soaring divorce rates of older couples in Japan (Kenyon Paul, 2006). Recent evidence for Italy, also points to soaring divorce rates of older individuals around retirement age (Corriere della Sera, 2011, La Repubblica, 2014). Interestingly, Italy and Japan stand out as the OECD countries in which married men contribute the least to housework (see OECD, 2001, and Burda, Hamermesh and Weil, 2013).

\footnotetext{
${ }^{2}$ Other social scientists provide descriptive evidence of a negative association between retirement, gender roles and the quality of marriage (Moen, Phillys, Jungmeen E. Kim, and Heather Hofmeister, 2001) using a two years panel on American couples, ignoring though the possibility of reverse causation and the potential endogeneity of the timing of retirement in their model of marriage quality changes at retirement.

${ }^{3}$ The patterns are similar for the younger generation and show pronounced increases in divorce rates since the nineties. For each older age group, there are many more divorces for men than for women, which is explained by the fact that men marry (and divorce) on average younger women.
} 
The costs of divorcing at older age are likely to be large for the economy and society at large, as older people are less likely to remarry and may depend more heavily on the welfare state while family providers of unpaid care will have to split their time between two parents.

Here, we exploit information on the socio-economic status of the father of the respondent, focusing on individuals that were raised in farmer households, to capture how growing in an environment in which gender roles are likely to be very traditional, with fathers contributing little to domestic work and both spouses working very long hours, ${ }^{4}$ may affect individual marital stability at the time of transiting into retirement. Over twenty per cent of the individuals in our sample come from a household in which the father was a farmer. Divorce rates increased dramatically for all socio-economic groups over the period of time covered by our data. By 2002, about five per cent of older men whose father was a farmer were divorced against almost fourteen per cent of men whose father was a University professor or a secondary school teacher. In particular, individuals whose father was a farmer have slightly more children than others, and their marriage is characterized by larger age and education differences between spouses (according to evidence we draw from data on French married couples), which may also characterize more traditional marriages (see Bloemen and Stancanelli, 2014). ${ }^{5}$ Interestingly, data on time allocation in France indicate that male farmers spent on average, three hours a week on housework at the end of the nineties, against an average of eleven hours for the average married man, and both spouses in a farmer household enjoyed only twelve hours of pure leisure per week at most, against more than eighteen hours for the average French married spouses. Data drawn from the French Consumption Survey of 2000 , suggest that consumption does not drop substantially in farmers' household when the head turns 60 (see also Moreau and Stancanelli, 2014). Although farms have been steadily disappearing over time, France still counted 515000 farms in 2010 (with an average surface of over 100 hectares per farm), which represent $4.3 \%$ of the 12 million European Union farms (INSEE, 2014) while in the USA there were over 2 million farms at about the same time. This implies that the implications of our analysis may concern a non-negligeable fraction of households. Traditional gender roles are not the resort of men only but they can also be internalized by women and more generally, by both spouses. Remarkably, Fernandez, Fogli and Olivetti (2004), analyzing the determinants of the secular right of female labor force in

\footnotetext{
${ }^{4}$ This argument is supported by evidence drawn from the 1998-99 French time use survey (see Table ). See also, for example, Meiners Jane E and Geraldine I. Olson (1987) on time allocation of American female farmers and Annie Rieu (2004) on the economic situation of French women in agriculture.

${ }^{5}$ According to Chiappori, Pierre-André, Oreffice, Sonia and Climent Quintana-Domeque (2012), the less attractive partner may compensate the other financially.
} 
the USA, find that women married to a man whose mother worked are themselves more likely to participate in the labor force. Here, we find that both men and women who grew up in a farmer household are more likely to experience marriage instability at the time of transiting into retirement and this finding is robust to various sensitivity checks.

Marital instability may not be independent from the timing of divorce -as marriage stability may, for example, also affect productivity and employment- and individuals may have incentives to time their divorce a retirement as they will have more time available to file for divorce then. To identify the effect of retirement on marital stability, we exploit legal retirement age in France to instrument the timing of individual retirement, applying a fuzzy regression discontinuity design. Using data drawn from the French Labor Force Surveys on sample of over 200000 men and over 166000 women aged 50 to 70 years, we conclude that the probability to retire increases significantly when individuals turn 60 and the size of the increase is equal, respectively, to about $0.19-0.23$ for men and 0.25-0.29 for women, which supports our identification strategy. The probability to divorce upon retirement increases significantly and almost doubles for individuals of either gender that grew up in traditional households in which the father was a farmer, raising respectively, by 0.04 to 0.010 for men and by 0.6 to 0.08 for women. These findings are robust to various specification checks.

This paper is structured as follows. The empirical approach is described next. The data used for the analysis and the sample selection criteria are presented in Section 3. Descriptive analysis follows. The results of estimation are presented in Section 5. Conclusions are drawn in Section 6.

\section{The empirical model}

Because retirement is likely to be anticipated (see the pioneering work of Gary Becker, Elisabeth Landes and Robert Michael (1977), we would not expect a priori a significant effect of retirement on divorce. Upon retirement though, partners may want to renegotiate the household allocation of time which may possibly lead to marital conflict. Moreover, retirement may challenge traditional gender roles and this may also upset marital stability. Women perform traditionally more house work than men do and thus female retirement may represent less of a challenge for the household time allocation than male retirement does. Moreover, the wife is often younger than the husband and thus, the last to retire. Therefore, we do not expect to find symmetric effects of male and female retirement on divorce rates. Because earlier literature suggests that the woman is often the one that initiates the divorce 
even when the woman loses financially from the divorce (see Margaret Brining and Douglas Allen, 2000), she may be even more likely to do so if loosing spousal pension benefits is not at stake (there are no spousal benefits in France) and children are already grown up and have left home (which is typically the case by the time parents retire). This implies that retirement may well cause divorce which is something that has not been considered before in the economic literature. Since individuals are going plan their retirement well in advance - in France, for example, they have to notify social security officers at least four months earlier that they plan to retire at a certain date- the prospects of retirement may affect marriage stability well before actual retirement takes place. The actual retirement may just be the last drop that spills the (marriage) cup over or say, the last straw that breaks the (marriage) camel's back. Therefore, we may find an immediate positive effect of retirement on individual divorce rates. In particular, we expect that individuals that grew up in more traditional family environment may see their marital life particularly proven at the time of retirement, since they have been exposed during youth to stronger gender roles and gender specialization in household tasks (see Table 5 below; and for example, Jane Meiners and Geraldine Olson (1987) for an account of time allocation of USA female farmers or Annie Rieu (2004) on the situation of women farmers in France), which implies that they may have more difficulties to adjust to the dramatic change in time allocation at retirement, when work at the office is over and individuals are "forced" to reallocate their time between leisure and house work. This is especially true in the French context of highly regulated retirement age.

Because the individual decision to retire from work may not be independently determined from marriage (in)stability-for example, individuals in (un)stable marriages may be more (less) productive at work and this may affect the timing of their retirement- we exploit the legislation in France that sets 60 as the earliest retirement age for most workers to instrument the effect of retirement in our divorce model. The existence of a legal retirement age creates a discontinuity in the probability of retirement (as a function of age) that enables us to apply a regression discontinuity approach. Excellent literature reviews of regression discontinuity methods are provided, for example, by David Lee and Thomas Lemieux (2010), Wilbert van der Klaauw (2008), or Guido Imbens and Thomas Lemieux (2007). The main advantage of regression discontinuity over other competing approaches is that it is closer to a natural experimental design as individuals close to the discontinuity are likely to be very similar and the only thing that makes them differ is the option to retire once they reach legal retirement age. Thus, we can neatly identify the effect of retirement (instrumented with the legal 
retirement age) on marriage outburst. Under this set up, the identification of the effect of retirement on the individual probability to divorce (the outcome variable) is achieved thanks to the sudden and large increase in retirement (the treatment) at the point of discontinuity (age 60 ) in the running variable (age). Individuals cannot manipulate their age -and this is one of the requirements for using a regression discontinuity approach (see, for example, Lee and Lemieux, 2010). In our data, year and month of birth were collected, and we also know the day, month and year of the survey interview. Therefore, we assume that age is measured continuously. There are no other policy measures that affect individuals reaching age 60 in France. ${ }^{6}$ Retirement is also measured at the time of the interview. However, we need to account for the fact that some people may retire earlier than sixty ${ }^{7}$-due to special early retirement schemes or specific employment sector rules - and others later, though in France, unemployment, maternity and sick leave periods are fully covered by pension rights, so that interrupted labour market experience will not translate into smaller pension benefits or into a longer working life. ${ }^{8}$ We use a so-called Fuzzy Regression Discontinuity design - the jump in the probability of retirement at age 60 (or 720 months) is greater than zero but less than one. ${ }^{9}$

Let $\mathrm{R}_{i j}$ be a dummy for retirement equal to one if individual $i$ has retired from market work and zero otherwise. Let $D_{i}$ be a dummy that takes value one when individuals have reached age 60 (720 months of age) and zero otherwise, and let $S_{i}$ be the divorce outcome. The fuzzy regression discontinuity design can be estimated by specifying a two stages least square model of the effect of retirement -instrumented with a dummy for being aged at least 60 (720 months or more) and full interactions of this dummy with an individual age polynomial- on divorce (see Hahn, Jinyong; Petra Todd; Wilbert Van der Klaauw (2001).

$$
\text { 1) } \begin{aligned}
& \mathrm{S}_{\mathrm{i}}=\alpha^{\mathrm{c}}+\mathrm{R}_{\mathrm{i}} \beta^{\mathrm{c}}+\left(\text { Age }_{\mathrm{i}}-720\right) \gamma^{\mathrm{c}}+\left(\mathrm{Age}_{\mathrm{i}}-720\right)^{2} \gamma^{\mathrm{c} 2}+\left(\text { Age }_{\mathrm{i}}-720\right)^{3} \gamma^{\mathrm{c} 3}+\left(\mathrm{Age}_{\mathrm{i}}-720\right)^{4} \gamma^{\mathrm{c4}}+ \\
& +\mathrm{D}_{\mathrm{i}}\left(\text { Age }_{\mathrm{i}}-720\right) \delta^{\mathrm{c}}+\mathrm{D}_{\mathrm{i}}\left(\text { Age }_{\mathrm{i}}-720\right)^{2} \delta^{\mathrm{c} 2}+\mathrm{D}_{\mathrm{i}}\left(\text { Age }_{\mathrm{i}}-720\right)^{3} \delta^{\mathrm{c} 3}+\mathrm{D}_{\mathrm{i}}\left(\text { Age }_{\mathrm{i}}-720\right)^{4} \delta^{\mathrm{c} 4}+Z_{i} \beta^{\mathrm{c}}+v_{\mathrm{i}}^{\mathrm{c}}
\end{aligned}
$$

\footnotetext{
${ }^{6}$ Other policies are targeted at older unemployed workers, aged 55 and above, that are allowed not to search for jobs ("dispenses the recherches d'emploi") or at employers, that have to pay some large penalty to be able to fire older workers, aged above 55 ("Contribution Delalande").

${ }^{7}$ The pension benefits payable reach a maximum when individuals have cumulated a given contribution record (for example, 40 years of contributions in 1994 for people born in 1944 and working in the private sector). Once individuals have contributed enough to retire with maximum (full) pension benefits, their pension benefits will not increase if they retire later. Furthermore, periods of unemployment or sick leave, including maternity and parental leave, all lead to full (100 per cent coverage of) pension contribution records.

${ }^{8}$ See, for example, Blanchet and Pele (1997) for more details of the French pension system. In 2010, the legal early retirement age was set at 62 years, but this will become effective only in 2018 .

${ }^{9}$ An application of regression discontinuity to the retirement decision is given in Stancanelli and van Soest (2012) who investigate the effect of partners' retirement on time allocation and notably, house work.
} 
2) $\mathrm{R}_{\mathrm{i}}=\alpha^{\mathrm{r}}+\mathrm{D}_{\mathrm{i}} \mu^{\mathrm{r}}+\mathrm{D}_{\mathrm{i}}\left(\right.$ Age $\left._{\mathrm{i}}-720\right) \delta^{\mathrm{r}}+\mathrm{D}_{\mathrm{i}}\left(\text { Age }_{\mathrm{i}}-720\right)^{2} \delta^{\mathrm{r} 2}+\mathrm{D}_{\mathrm{i}}\left(\text { Age }_{\mathrm{i}}-720\right)^{3} \delta^{\mathrm{r} 3}+\mathrm{D}_{\mathrm{i}}\left(\text { Age }_{\mathrm{i}}-720\right)^{4} \delta^{\mathrm{r} 4}+$ $+\left(\right.$ Age $_{\mathrm{i}-720)} \gamma^{\mathrm{r}}+\left(\mathrm{Age}_{\mathrm{i}}-720\right)^{2} \gamma^{\mathrm{r} 2}+\left(\mathrm{Age}_{\mathrm{i}}-720\right)^{3} \gamma^{\mathrm{r} 3}+\left(\mathrm{Age}_{\mathrm{i}-}-720\right)^{4} \gamma^{\mathrm{r} 4}+\mathrm{Z}_{\mathrm{i}} \beta^{\mathrm{r}}+v_{\mathrm{i}}^{\mathrm{r}}$

Equation 1 is the outcome equation for divorcing (S) and equation 2 is the first stage equation for retirement in our Fuzzy Regression Discontinuity model. We specify a quartic flexible polynomial in age and test for the robustness of our estimates to using a different degree of the age polynomial. The threshold 720 months corresponds to the minimum legal retirement age for most workers in France. We assume that the covariates other than age (denoted by $\mathrm{Z}$ here) are not discontinuous at age 60 (and we also test for this). The vector $\mathrm{Z}$ includes individual education dummies, the number of children still living at home, year (we cover a thirteen years period) and district (95 departments) fixed effects, the level of the district unemployment rate a year before the survey, the individual "sex-ratio", which serves as a measure of tensions in the marriage market (see Section 3 for definitions). The errors $v$ is assumed to be normally distributed. The two equations are estimated by two stages least squares. We also adjust the standard errors of the model as recommended in the related literature. Finally, we also run similar models for the outcomes of widowhood (placebo), marriage, or singlehood.

\section{The data}

The data for the analysis are drawn from the French Labour Force Surveys (LFS) 1990-2002. We use this sample cut for a number of reasons. First of all, these yearly surveys are highly comparable over time as they use the same questionnaire, the same data collection method (personal interviews at the respondent's home) and the same sample design approach. The LFS series was broken in 2003 to comply with Eurostat requirements. The recent LFS surveys (as from 2003) are carried out quarterly and most of the interviews are done by telephone; and the questionnaire and the sample design have changed dramatically relative to the earlier 1990-2002 surveys. In addition, a reform of the length of the pension contribution period took place in $2003,{ }^{10}$ exactly at the time of the break in the LFS series, and divorce law was also reformed in 2004. Therefore, we select a sample of individuals from the 1990-2002 yearly LFS as follows:

1. Individuals reported as the main economic situation either employment or retirement at the interview date.

\footnotetext{
${ }^{10}$ Also a substantial reform of survivor pensions took time in 2003 , which is when the LFS surveys were also broken up.
} 
2. Individuals were aged between 50 (or 600 months) and 70 (or 840 months) at the interview date to set ten year bounds on the two sides of the discontinuity at age 60 (or 720 months), which is the legal minimal retirement age for most workers in France.

This lead to selecting, respectively, a main sample of 202606 men and 166162 women, that were either retirees or employees, and aged 50 to 70 years at the time of the survey. The LFS collects month and year of birth together with records of the day, month and year of the interview. Therefore, we construct an approximately continuous measure of age in days, on the day of the interview, assuming that individuals were born on the $15^{\text {th }}$ day of the month. We also checked the robustness of the results to measuring age in months and results were not affected. The retirement status is subjectively assessed by the individual and measured on the interview date. In particular, the individual could choose among reporting that his/her main economic status was employment, or unemployment, in full-time education, a military, retirement or early retirement, being a housewife or other inactive. Marital status was also self-assessed and individuals were classified as married, cohabiting, single, divorced or widowed at the date of the interview. It follows that individuals that separated and were not (yet) formally divorced might classify themselves as any of these four possibilities, though it seems likely that they would report to be "divorced" rather than reporting to be still formally married or single and thus, we can think of our dependent (outcome) variable as encompassing either divorce or separation.

As far as the explanatory variables go, we also construct categorical dummies for the occupation of the father of the respondent (see Appendix for more details of the various occupations coded), which we expect to capture the effect of the individual socio-economic background and in particular, the type of household individual grew up in. We do not control for own occupation for a number of reasons. First of all, occupation may be endogenous as individual choose their occupation. Next, current occupation is obviously only recorded for individuals still at work while occupation in the last job is available for retirees but the code is slightly different than that for current occupation and moreover, individuals may have changed occupation over the life-cycle.

We also control for completed education dummies - the excluded group being individuals with college education. The most disaggregated area of residence or say district, available in the survey is the "department". France is divided into 22 regions that are further subdivided into 95 districts ('departments') - without considering the overseas territories (French Guyana, 
Guadeloupe, Martinique, Mayotte, Ile de la Reunion) that were not covered by these surveys. The level of the unemployment rate may affect the individual retirement probability as, for example, employers may encourage older workers to retire in recessionary times. Therefore, we construct a measure of the local unemployment rate, using the level of the departmental unemployment rate in the year before each survey was carried out. We also include district (“department") fixed effects and year dummies. The latter which are meant to capture macroeconomic changes and notably the secular increase in female labour supply. Finally, we constructed a measure of tensions in the marriage market, the "sex-ratio", defined as the ratio of the number of men born in the same year as the individual under consideration to the number of women born two years later, since the average age difference between older spouses in France at the time covered by this study was two years (see for example, Hans Bloemen and Elena Stancanelli, 2014, on younger French spouses, for whom the average age difference is also two years). We also test for the robustness of the estimates to including birth cohort dummies, defining 5 years birth intervals.

\section{Descriptive analysis}

Sample descriptive statistics are shown in Table 1. About 5.5\% of the men in the sample were divorced against almost $9 \%$ of the women, on average. Marriage was much more common among older men (remember our sample includes individuals aged 50 to 70 years) than among older women: 85 per cent of the men were married against $68 \%$ of the women. In contrast, widowhood concerned more often women than men: $16.5 \%$ of the women in the sample against only $3 \%$ of the men. This is due to longer life expectancy for women and also possibly to the fact that older (widowhood) men are perhaps more likely to remarry than older (widowhood) women. The proportion of singles was only slightly larger in the older women's sample (almost 6\%) than in the older men's sample (almost 5\%). The average sex ratio for the individuals in the sample was almost 0.47 , indicating that there were 0.47 men on average for each two-years-younger woman. The local unemployment rate at the time was high, equal on average to $9 \%$. As far as retirement goes, $55 \%$ of the men and almost $57 \%$ of the women in the sample were retirees.

Divorces are more frequent among college graduates and increase proportionally with the individual education level: almost $7 \%$ of male college graduates in our sample were divorced against $4.5 \%$ of individuals with less than middle school (see Table 2). Women are generally more likely to remain divorced than men are, as they are less likely to remarry, and especially 
so at older age. The differences are even more striking when divorcees are counted by the father's employment type (see Table 3), with older men whose father was a farmer being the least represented among divorcees (less than 2 per cent of them were divorced in 1990) and older men whose father was a secondary school or University teacher registering the highest number of divorces $(9.3 \%$ of them were divorced in 1990). The trend is towards increasing divorce rates (as also shown in Figures 1 and 2) with soaring divorce rates of men whose father was a teacher, almost $14 \%$ of whom were divorced by 2002 against $5.6 \%$ of men whose father was a farmer (see Table 3).

Remarkably, over 30 per cent of the individuals in our older population sample had the same type of employment than their father, though the proportion of individuals holding the same employment type as their father is falling over time for both men and women (see Table 4). The correlation between the own and the father's employment fell over time but it was still very sizable throughout our sample period, averaging about 27 per cent for men and 31 per cent for women (see Table 4).

To gain more insights into the implications of stratifying the sample by father's employment state, we gather some descriptive information on marriage-match characteristics, consumption and time allocation of married individuals classified according to the father's employment sector (see Table 5). In particular, couples in which the father of the husband was a farmer appear to be slightly more fertile than others and the age difference between the husband and the wife is slightly larger than for other socio-economic backgrounds. The proportion of housewives in these couples is slightly lower than for other socio-economic background. In line with this, we also find that in current farmer couples, partners tend to enjoy fewer "pure" leisure hours than others -defining "pure" leisure as performing sports, socializing, reading, or watching television- and the husband contributes considerably less than the average to unpaid domestic work. This evidence tends to confirm that men in farmer household perform little domestic work and both spouses work harder on average than the average. Although, we only have a limited number of observations in each cell, which makes generalizations difficult to carry out, we compare total household consumption and wealth returns before and after retirement age for couples of farmers and couples with other employment types, to conclude that the drop in the returns from wealth upon retirement is not especially large for farmer households while the drop in consumption is smaller for farmer than for individuals in top occupations. This is in line with Nicolas Moreau and Elena Stancanelli (2014) who find no significant changes in total consumption upon spouses' retirement in France. 
Finally, to verify that we can apply a regression discontinuity approach to our sample of older individuals, we applied a Mc Crary test (see Justin McCrary, 2008) to check the continuity of the running variable (age) on the two sides of the age cut-off at 720 months of age (age 60) and plot the Mc Crary DC density function to shows no discontinuity in age, as required for the approach in this study (see Figures 3A for the sample, and 3B for the subsample of individuals whose father was a farmer). Next, we investigated that the " $Z$ " covariates are smooth on the two sides of the age cut-off (60 years or 720 months, since we measure age in months) and by compliance status (retirement here). We find that individuals with college education are somewhat less likely to retire at age 60 than individuals with lesser education since the more educated are likely to have entered the labor market later and thus, have cumulated fewer pension contribution than the lesser educated (see Table 6 , for men). We also repeat this exercize for men whose father was a farmer (see Table 7, again for men). We also test graphically that the covariates are smooth at age 60 by plotting predicted divorce rates by gender (predicted as a function of the Zs) against age (see Figure 6).

Then, as customary when applying a Regression Discontinuity approach, we present some exploratory graphical analysis of the retirement probability and the outcome variables as a function of the running variable (age) by bins of ten months of age for men and women (see Figures 4A, 4B, 4C and 4D, respectively) and also for the subsample of individuals whose father was a farmer (see Figures 5A, 5B, 5C and 5D). We detect large jumps in the retirement probability upon reaching age 60 (720 months) for both men and women in the main sample and in the subsample of individuals whose father was a farmer (see Figures 4A and 5B, respectively). Figure 5B also suggests an increase in divorce rates upon turning 60 (720 months here) for men and women whose father was a farmer. The evidence for the full sample of men and women is much less clear-cut (see Figure 4B). We find no detectable increase in the chances of widowhood upon turning 60 (see Figure 4D or 5D) while the patterns are complex for marriage (Figure 4C and Figure 5C, respectively), with a turning point slightly before age 60 for men and a steady decline for older women.

\section{Results of estimation}

We expect that retirement may have a possibly deterrent effect on marriage stability and especially so for individuals with more traditional allocation of time and gender roles. We have estimated two-stages-least-squares models of the effect of individual retirement (instrumented with a dummy for reaching legal retirement age, 720 months of age, and full 
interactions of this dummy with a quartic age polynomial) on the individual chances to divorce. These models were estimated separately for men and women and for subsamples of individuals by own education level and by father's socio-economic state. We tested for the robustness of the estimates to using different degree of the age polynomials as well as including and excluding covariates and narrowing the sample age boundaries on the two sides of the age cutoff. Finally, we also estimated similar models for different marriage status outcomes including marriage, singlehood and widowhood (placebo).

First of all, we find that retirement increases sharply and strongly (significant at the 1\% level) upon reaching age 60 (720 months) for both men and women (see Tables 8 and 9). The estimates of the increase in retirement upon reaching legal retirement age are robust to all specification checks and, equal to $019-0.23$ for men and 0.22-0.29 for women. The effect of turning 60 years on the retirement probability remains strongly significant (at the one per cent statistical significance level) and is only slightly smaller in size when narrowing the sample bounds on the two sides of the age cut-off, restricting the sample to individuals aged, respectively, 52 to 68 years or 54 to 66 years (see Tables 8 and 9, Specifications 9 to 12). Thus, we are comforted that our identification strategy is valid.

We find no significant change in the probability to divorce for men, except when using a quadratic age polynomial (see Table 8 , Specification 5, without covariates, and 6, including covariates). Under this specification, the chances to divorce increase significantly by 0.03 upon male retirement, which represents a large increase in divorce rates -the share of divorces in the sample is equal to 0.05 for men aged 59 to less than 60 years, close to the legal retirement age discontinuity. We find no effect of retirement on female divorce rates (see Table 9). However, when restricting attention to individuals whose father was a farmer, retirement is found to increase significantly divorce rates upon both male and female retirement (see Tables 10 and 11). In particular, the probability to break up increases by 0.045 to 0.11 upon male retirement and by 0.06 to 0.08 upon female retirement for individuals whose father was a farmer. These findings are robust to numerous specification checks such as using degree of the age polynomial or narrowing the sample bounds on the two sides of the age discontinuity or dropping individuals that are age 60 from the sample (see the bottom blocks of results in Tables 10 and 11, respectively). They are also robust to including birth cohort dummies grouped into five years intervals or to observations dropping the early nineties Labor Force Surveys or from the 2000s (see Table 12). 
In contrast, retirement does not affect divorce rates of individuals with other social-economic background (see Table 13), except for women issued the families in which the father was a blue collar (manual worker in factories or rural worker) for whom divorce rates drop significantly at retirement. Splitting the sample by education level, we do not find any significant effect of male retirement on divorce rates (see Table 14), except for female retirement that reduces significantly the chances to divorce for women that have completed middle education. These women may overlap with those issued from a family with a blue collar father. This finding could perhaps be explained by the type of men these women marry that might on average more educated and wealthier and perhaps more involved in domestic work, something we cannot test with the data to hand.

Finally, we find no significant effect of retirement on either marriage or widowhood or singlehood, as expected (see Table 15). Table 16A and Table 16B present the full-sets of results for the sample and the subsample of individuals whose father was a farmer. Interestingly, the presence of children reduces significantly the chances of marriage break up for all sample cuts.

\section{Conclusions}

This paper studies the effect of individual retirement on divorce, an issue which has received no attention in the economic literature to date. Retirement may upset marital stability as it represents a dramatic change in individual time allocation that may undermine gender identity and traditional gender roles in the household. Moreover, by the time of retirement, children that often hold the couple together are likely to have left home. Since individuals start planning their divorce well in advance -also to comply with advance notice requirements to employers and social security offices- the actual time of divorce may be the last drop that spills over the (marriage) cup.

Because the individual decision to retire from work may not be independently determined from marriage (in)stability -for example, individuals that expect to divorce may retire earlier or later than others- we exploit legal retirement age in France to identify the effect of male and female retirement on the individual probability to divorce. Using data drawn from the French Labor Force Surveys on sample of over 200000 men and over 166000 women aged 50 to 70 years, we conclude that the probability to retire increases significantly when individuals turn into legal retirement age, which support our identification approach. We find that the probability to divorce upon retirement increases significantly for individuals that grew 
up in a farmer household. Indeed, individuals that grew up in more traditional family environment may see their marital life particularly proven at the time of retirement, since they have been exposed during youth to stronger gender roles and gender specialization in household tasks, which implies that they may have more difficulties to adjust to the dramatic change in time allocation at retirement, when work at the office is over and individuals are "forced" to reallocate their time between leisure and house work. This is especially true in the French context of highly regulated retirement age.

Our findings are robust to various specification checks. In particular, the probability of marriage breaks up increases by 0.045 to 0.11 upon male retirement and by 0.06 to 0.08 upon female retirement for individuals whose father was a farmer. These represent an almost doubling of the probability to divorce for these individuals upon retirement. Finally, there is no effect of retirement on (re)marriage. ( $\mathrm{Re}$ )-marriage prospects start falling for men before the actual time of retirement and are thinner all the way through for older women. We also conclude that retirement has no effect on singlehood or widowhood, which serves as a placebo test.

Although farms have been steadily disappearing over time, France still counted 515000 farms in 2010, which represent $4.3 \%$ of the 12 million European Union farms while in the USA there were over 2 million farms at about the same time. It follows that the implications of our analysis may concern a non-negligeable fraction of households. Traditional gender roles are not the resort of men only but they can also be internalized by women and more generally, by both spouses. Earlier literature, analyzing the determinants of the secular right of female labor force in the USA, find that women married to a man whose mother worked are more likely to participate in the labor force. Here, we find that both men and women who grew up in a farmer household are more likely to experience marriage instability at the time of transiting into retirement and this finding is robust to various sensitivity checks.

\section{Bibliography}

Aguiar, Mark, and Eric Hurst (2005), "Consumption versus Expenditure." Journal of Political Economy, 113(5): 919-948.

Aguiar, Mark, and Eric Hurst (2007), "Life-Cycle Prices and Production." American Economic Review, 97(5): 1533-1559.

Akerlof, George A. and Rachel E. Kranton (2000), Economics And Identity, The Quarterly Journal of Economics, MIT Press, vol. 115(3), pages 715-753, August. 
Becker, Gary S., Elisabeth M. Landes and Robert T. Michael (1977), “An Economic Analysis of Marital Instability”, Journal of Political Economy, Vol. 85, No. 6, pp. 1141-1187.

Blanchet, Didier and Louis-Paul Pele (1997), Social Security and Retirement in France, NBER Working Paper No. 6214.

Bloemen, Hans and Stancanelli, Elena (2014), "Toyboys or Supergirls? An analysis of partners' employment outcomes when she outearns him", Review of the Economics of the Household, forthcoming.

Brining, Margaret F. and Allen, Douglas W. (2000), "These Boots are Made for Walking": Why Most Divorce Filers Are Women”, American Law and Economics Review, pp. 126-169.

Burda, Michael, Daniel S. Hamermesh and Philippe Weil (2013), Total work and gender: facts and possible explanations, Journal of Population Economics, 26(2), 507-530.

Chiappori, Pierre-André, Oreffice, Sonia and Climent Quintana-Domeque (2012), "Fatter attraction: anthropometric and socioeconomic matching on the marriage market", Journal of Political Economy, 120(4), 659-695.

Corriere della Sera, 8 luglio, 2011

http://archiviostorico.corriere.it/2011/luglio/08/Nuova_vita_dopo_anni_Raddoppiati_co_8_11 0708043.shtml

Faiola, Anthony (2005). "Sick of Their Husbands in Graying Japan". The Washington Post. Retrieved 2006-11-29.

Fernández, Raquel, Fogli, Alessandra and Claudia Olivetti, 2004. "Mothers and Sons: Preference Formation and Female Labor Force Dynamics", The Quarterly Journal of Economics, MIT Press, vol. 119(4), pages 1249-1299, November.

Gopi Shah Goda, John B. Shoven, Sita Nataraj Slavov (2007), "Social Security and the timing of divorce", NBER Working Paper 13382

Gruber, Jonathan and David Wise (2005), "Social Security Programs and Retirement around the World: Fiscal Implications, Introduction and Summary,"NBER Working Papers 11290, National Bureau of Economic Research, Inc

Hahn, Jinyong; Petra Todd; Wilbert Van der Klaauw (2001), Regression-Discontinuity Design, Econometrica, 69 (1), pp. 201-209.

Imbens, Guido and Thomas Lemieux (2007), Regression Discontinuity Design: a Guide to Practice, Journal of Econometrics, 142, 615-635.

INSEE, Exploitations Agricoles (2014), web document, http://www.insee.fr/fr/themes/document.asp?ref_id=T13F172

Kenyon, Paul (2006), "Retired husband syndrome". BBC News, This World, November 13, 2006. 
La Republica, 22 marzo, 2014,

http://www.repubblica.it/cronaca/2014/03/22/news/matrimoni resistono al sud di meno al nord ma la rete fa tradire-81599012/

Lee, David S. and Thomas Lemieux (2010), Regression Discontinuity Designs in Economics, Journal of Economic Literature, 48(2), 281-355.

McCrary Justin, "Manipulation of the Running Variable in the Regression Discontinuity Design: A Density Test,” Journal of Econometrics, 142 (2008), pp. 698-714.

Meiners Jane E and Geraldine I. Olson (1987), "Household Paid and Unpaid Work Time of Farm Women", Family Relations, Vol. 36, No. 4, Rural Families: Stability and Change (Oct., 1987), pp. 407-411.

Moen, Phillys, Jungmeen E. Kim, and Heather Hofmeister (2001), “Couples'

Work/Retirement Transitions, Gender, and Marital Quality," Social Psychology Quarterly, 64 (1), pp. 55-71.

Meyer, Bruce D. and Wallace K.C. Mok (2013), "Disability, Earnings, Income and Consumption," NBER Working Papers 18869.

Moreau, Nicolas, and Elena Stancanelli (2014), "Household Consumption at Retirement: a Regression Discontinuity Study on French Data", Annales d'Economie et Statistique, forthcoming.

OECD (2001), "Balancing Work and Family Life: Helping Parents into Paid Employment", Chapter 4, Employment Outlook, June 2001, pp. 129-162.

Pollak, Robert A. (2003), "Gary Becker's Contributions to Family and Household Economics," Review of Economics of the Household, 1 (1-2), pp.111-141.

Rieu, Annie (2004), “Agriculture et rapports sociaux de sexe. La « révolution silencieuse » des femmes en agriculture', Cahier du genre, 37, pp. 115-130.

Stancanelli Elena and Van Soest, Arthur (2012), "Retirement and Home Production: A Regression Discontinuity approach", American Economic Review, Papers and Proceedings, Vol 102 (3), pp. 600-605.

Stevenson, Betsey, and Wolfers, Justin (2007), "Marriage and Divorce: Changes and their Driving Forces", Journal of Economic Perspectives, American Economic Association, vol. 21(2), pages 27-52.

Van der Klaauw, Wilbert (2008), Regression-Discontinuity Analysis: A Survey of Recent Developments in Economics, Labour, 22(2), 219-245.

Van der Klaauw, Wilbert (2002), Estimating the Effect of Financial Aid Offers on College Enrollment: A Regression-Discontinuity Approach, International Economic Review, 43(4), 1249-1287. 
Figure 1. Divorced persons by year of the divorce and age of the divorcee. (As a proportion of the married population by gender in the same year). Source. French Ministry of Justice.

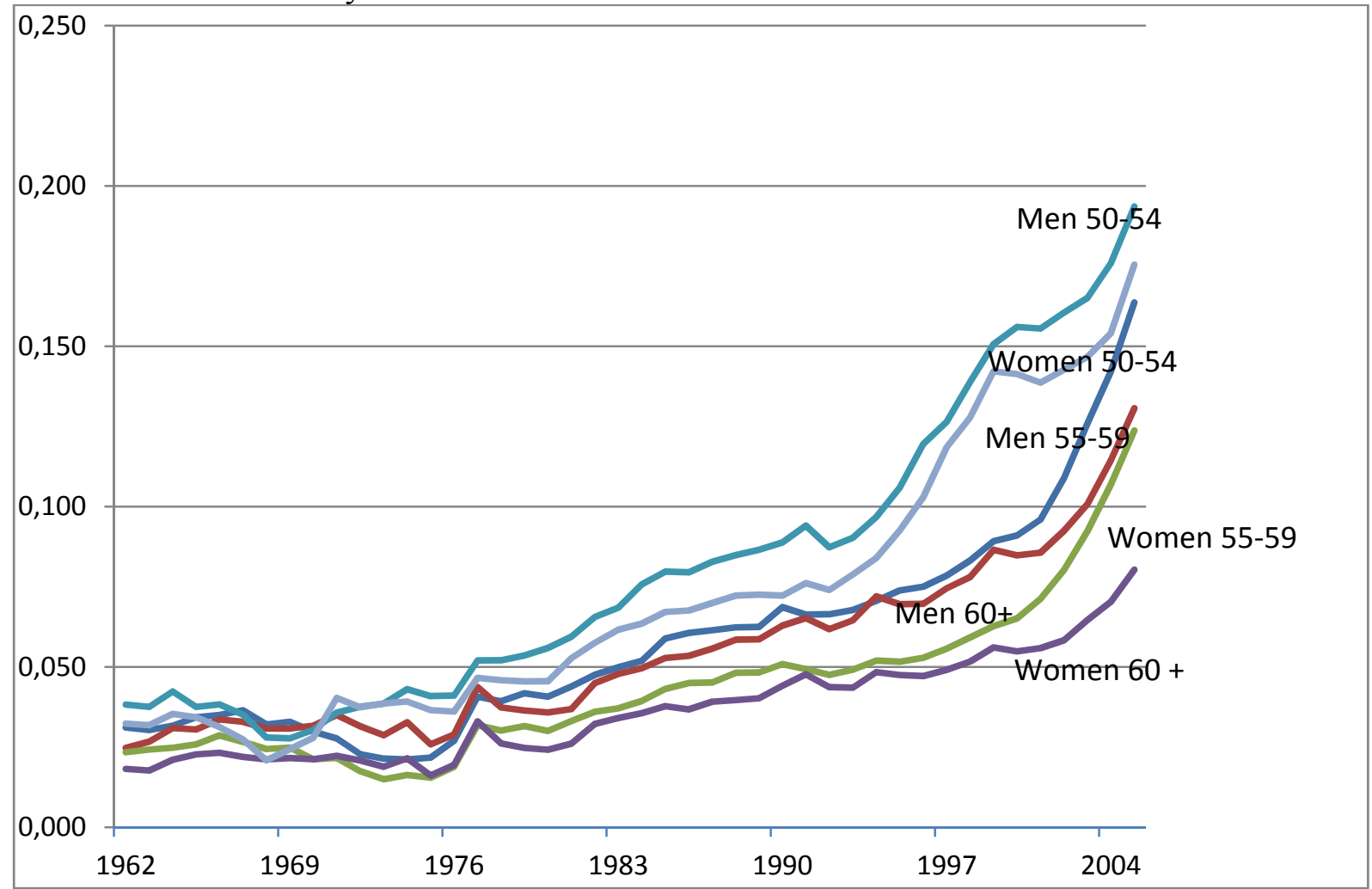


Figure 2. Divorced persons by year of the divorce and duration of the marriage (as a percentage of the married population in the same year)

Source. French Ministry of Justice.

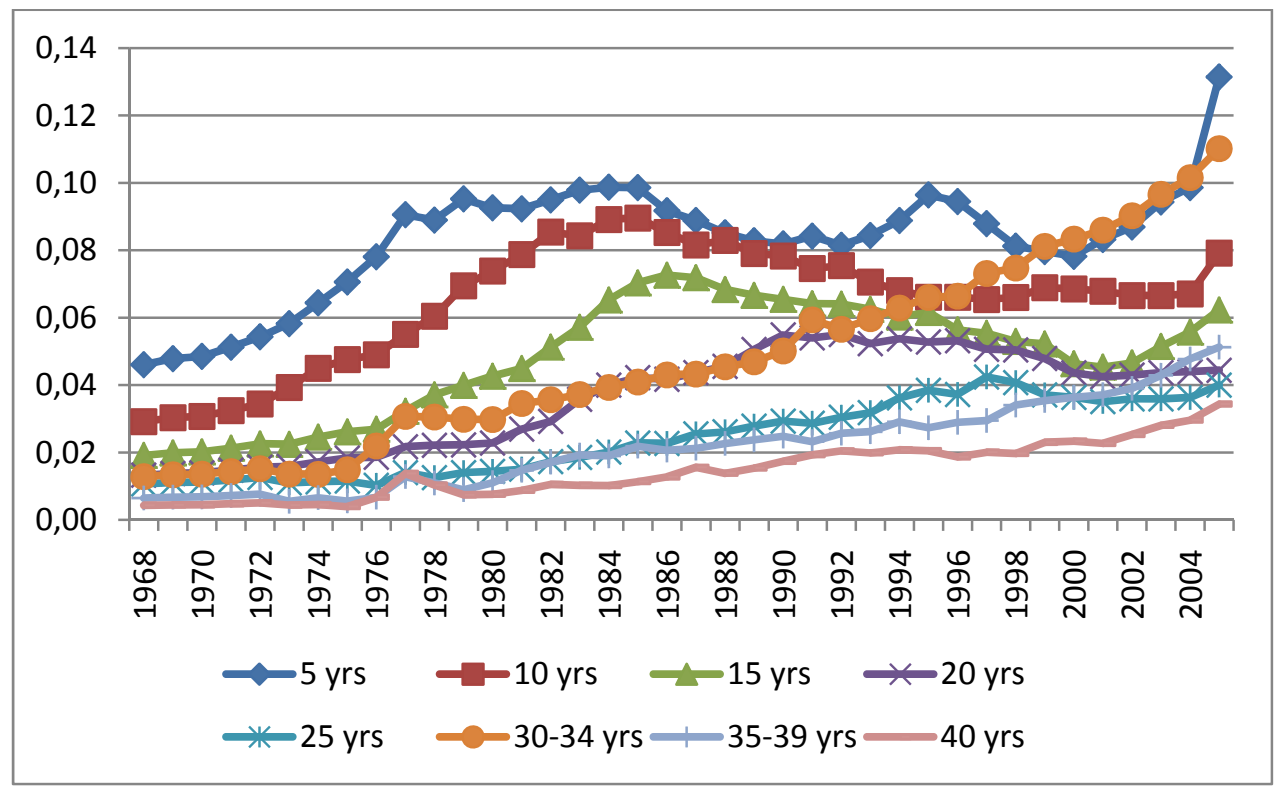




\begin{tabular}{|c|c|c|c|c|}
\hline & \multicolumn{2}{|c|}{ Sample of Men } & \multicolumn{2}{|c|}{ Sample of Women } \\
\hline & Mean & Std. Dev. & Mean & Std. Dev. \\
\hline Divorced & 0.055 & 0.227 & 0.089 & 0.284 \\
\hline Married & 0.852 & 0.354 & 0.681 & 0.466 \\
\hline Cohabitant & 0.034 & 0.182 & 0.031 & 0.173 \\
\hline Single & 0.047 & 0.213 & 0.057 & 0.232 \\
\hline Widow & 0.034 & 0.181 & 0.165 & 0.371 \\
\hline Retired & 0.552 & 0.497 & 0.568 & 0.495 \\
\hline aged $>=720$ months & 0.505 & 0.497 & 0.553 & 0.497 \\
\hline junior college & 0.037 & 0.19 & 0.061 & 0.239 \\
\hline high school & 0.078 & 0.269 & 0.073 & 0.260 \\
\hline middle school technical & 0.225 & 0.418 & 0.155 & 0.362 \\
\hline middle school & 0.051 & 0.221 & 0.083 & 0.276 \\
\hline less than middle school & 0.520 & 0.499 & 0.582 & 0.493 \\
\hline local U rate & 9.361 & 2.429 & 9.307 & 2.381 \\
\hline sex-ratio in birth year & 0.469 & 0.016 & 0.469 & 0.017 \\
\hline Observations & 202606 & & 166162 & \\
\hline \multicolumn{5}{|c|}{$\begin{array}{l}\text { Note: The reference category for the completed education dummies is having } \\
\text { a college degree. The sex ratio is the proportion of men born in the individual } \\
\text { year of birth over the proportion of women born two years later (as the } \\
\text { average age difference between partners is two years in France at the time } \\
\text { covered by the survey). }\end{array}$} \\
\hline
\end{tabular}




\begin{tabular}{|c|c|c|c|c|c|c|}
\hline \multirow[t]{3}{*}{ Table 2.} & \multicolumn{6}{|c|}{ Divorcees by education level and gender. } \\
\hline & \multicolumn{3}{|l|}{ Men } & \multicolumn{3}{|c|}{ Women } \\
\hline & Mean & St. Deviation & Obs. no. & Mean & St. Deviation & Obs. no. \\
\hline College (University) & 0.068 & 0.252 & 17520 & 0.145 & 0.352 & 7686 \\
\hline junior college & 0.080 & 0.271 & 7680 & 0.134 & 0.341 & 10144 \\
\hline high school & 0.074 & 0.262 & 15884 & 0.125 & 0.331 & 12134 \\
\hline middle school technical & 0.059 & 0.236 & 45679 & 0.101 & 0.302 & 25682 \\
\hline middle school & 0.065 & 0.247 & 10464 & 0.105 & 0.307 & 13763 \\
\hline less than middle school & 0.045 & 0.207 & 105379 & 0.070 & 0.254 & 96498 \\
\hline
\end{tabular}




\begin{tabular}{|c|c|c|c|c|c|c|c|c|}
\hline & \multicolumn{2}{|c|}{1990} & \multicolumn{6}{|c|}{2002} \\
\hline & Mean & St. Dev. & Obs. & Percentage & Mean & St. Dev. & Obs. & Percentage \\
\hline Farmers & 0.018 & 0.134 & 3642 & 24.63 & 0.056 & 0.229 & 3369 & 20.84 \\
\hline Craftmen & 0.034 & 0.180 & 1246 & 8.43 & 0.060 & 0.238 & 1141 & 7.06 \\
\hline shop keepers & 0.043 & 0.204 & 778 & 5.26 & 0.090 & 0.287 & 708 & 4.38 \\
\hline Business owners of $>=10$ persons & 0.104 & 0.307 & 134 & 0.90 & 0.088 & 0.284 & 171 & 1.06 \\
\hline Lawyers, consultants & 0.034 & 0.182 & 118 & 0.80 & 0.074 & 0.263 & 175 & 1.08 \\
\hline Public sector managers & 0.050 & 0.219 & 219 & 1.48 & 0.083 & 0.276 & 277 & 1.71 \\
\hline Teachers above primary school & 0.093 & 0.294 & 43 & 0.29 & 0.138 & 0.348 & 58 & 0.36 \\
\hline IT, Web, artists & 0.067 & 0.254 & 30 & 0.20 & 0.086 & 0.284 & 35 & 0.22 \\
\hline firm managers & 0.041 & 0.199 & 170 & 1.15 & 0.096 & 0.296 & 228 & 1.41 \\
\hline firm ingeneers and tech & 0.065 & 0.248 & 138 & 0.93 & 0.067 & 0.250 & 195 & 1.21 \\
\hline primary school teachers & 0.023 & 0.152 & 86 & 0.58 & 0.077 & 0.267 & 208 & 1.29 \\
\hline health and welfare workers & 0.049 & 0.218 & 41 & 0.28 & 0.088 & 0.285 & 57 & 0.35 \\
\hline Public sector supervisors & 0.030 & 0.173 & 131 & 0.88 & 0.086 & 0.281 & 163 & 1.01 \\
\hline $\begin{array}{l}\text { private sector supervisors } \\
\text { technical }\end{array}$ & 0.047 & 0.211 & 257 & 1.74 & 0.091 & 0.287 & 298 & 1.84 \\
\hline workers & 0.038 & 0.194 & 52 & 0.35 & 0.095 & 0.295 & 105 & 0.65 \\
\hline supervisors manufacture & 0.046 & 0.211 & 304 & 2.05 & 0.063 & 0.244 & 347 & 2.15 \\
\hline public sector workers & 0.032 & 0.175 & 411 & 2.78 & 0.076 & 0.266 & 509 & 3.15 \\
\hline military forces & 0.024 & 0.153 & 335 & 2.26 & 0.097 & 0.296 & 576 & 3.56 \\
\hline firm administrative workers & 0.039 & 0.193 & 618 & 4.18 & 0.080 & 0.272 & 833 & 5.15 \\
\hline sale assistants & 0.026 & 0.161 & 76 & 0.51 & 0.059 & 0.238 & 84 & 0.52 \\
\hline help sector workers & 0.053 & 0.224 & 171 & 1.15 & 0.081 & 0.273 & 173 & 1.07 \\
\hline skilled workers manufacture & 0.029 & 0.167 & 1075 & 7.27 & 0.082 & 0.275 & 1177 & 7.28 \\
\hline skilled workers craftmen & 0.034 & 0.182 & 991 & 6.70 & 0.078 & 0.269 & 1200 & 7.42 \\
\hline drivers & 0.050 & 0.220 & 237 & 1.60 & 0.087 & 0.282 & 357 & 2.21 \\
\hline transport and storage workers & 0.030 & 0.172 & 264 & 1.78 & 0.084 & 0.277 & 251 & 1.55 \\
\hline unskilled firm workers & 0.031 & 0.174 & 1415 & 9.57 & 0.076 & 0.265 & 2006 & 12.41 \\
\hline unskilled craf worker & 0.20 & 0.140 & 202 & 1.36 & 0.143 & 0.352 & 84 & 0.52 \\
\hline rural workers & 0.026 & 0.161 & 942 & 6.37 & 0.059 & 0.236 & 925 & 5.72 \\
\hline \multirow[t]{2}{*}{ Missing } & 0.032 & 0.175 & 662 & 4.48 & 0.096 & 0.294 & 459 & 2.84 \\
\hline & & & 14788 & 100 & & & 16169 & 100 \\
\hline
\end{tabular}

Table 4 . Raw correlation between individual occupation and their father's occupation.

\begin{tabular}{|c|c|c|c|c|c|c|}
\hline & \multirow{2}{*}{\multicolumn{3}{|c|}{$\begin{array}{l}\text { Men's main sample } \\
\text { Father's job }\end{array}$}} & \multicolumn{3}{|c|}{ Women's main sample } \\
\hline & & & & & & \\
\hline & 1990 & 1996 & 2002 & 1990 & 1996 & 2002 \\
\hline Last job occupied & 0.3685 & 0.3321 & 0.2678 & 0.3948 & 0.3765 & 0.3193 \\
\hline
\end{tabular}


Table 5. Descriptive information on spouses, consumption and time allocation from other data sources.

Labor force surveys 1990-2002: sample of married couples in which the husband was aged 45 to 55 years.

\begin{tabular}{|c|c|c|c|c|c|}
\hline & $\begin{array}{l}\text { Father } \\
\text { farmer }\end{array}$ & $\begin{array}{l}\text { Father top } \\
\text { occupation }\end{array}$ & $\begin{array}{l}\text { Father white } \\
\text { collar }\end{array}$ & $\begin{array}{l}\text { Father blue } \\
\text { collar }\end{array}$ & Sample \\
\hline \multirow[t]{2}{*}{ Wife is a housewife } & 0.238 & 0.255 & 0.22 & 0.258 & 0.245 \\
\hline & $(0.426)$ & $(0.436)$ & $(0.41)$ & $(0.437)$ & $(0.432)$ \\
\hline \multirow[t]{2}{*}{ Children at home number } & 1.57 & 1.44 & 1.30 & 1.35 & 1.41 \\
\hline & $(1.41)$ & $(1.22)$ & $(1.12)$ & $(1.22)$ & $(1.26)$ \\
\hline \multirow[t]{2}{*}{ Contractual hours husband } & 44.12 & 44.91 & 41.22 & 40.35 & 41.93 \\
\hline & $(12.02)$ & $(11.68)$ & $(9.65)$ & $(8.09)$ & $(10.09)$ \\
\hline \multirow[t]{2}{*}{ Contractual hours wife } & 34.67 & 34.46 & 34.60 & 33.84 & 34.30 \\
\hline & $(13.38)$ & $(12.14)$ & $(10.90)$ & $(11.45)$ & $(11.86)$ \\
\hline \multirow[t]{2}{*}{ Husband' age minus wife's } & 3.12 & 2.65 & 2.51 & 2.60 & 2.71 \\
\hline & $(4.12)$ & $(4.37)$ & $(4.25)$ & $(4.23)$ & $(4.28)$ \\
\hline \multirow[t]{2}{*}{ He less educated than she } & 0.13 & 0.11 & 0.12 & 0.125 & 0.120 \\
\hline & $(0.34)$ & $(0.31)$ & $(0.33)$ & $(0.330)$ & $(0.325)$ \\
\hline \multirow[t]{2}{*}{ She less educated than him } & 0.21 & 0.18 & 0.22 & 0.24 & 0.219 \\
\hline & $(0.41)$ & $(0.39)$ & $(0.41)$ & $(0.43)$ & $(0.414)$ \\
\hline Wife same father's background & $8.66 \%$ & $1.98 \%$ & $0.45 \%$ & 1.26 & $12.35 \%$ \\
\hline Observations & 20077 & 21020 & 23054 & 41542 & 110096 \\
\hline$\%$ & $18.25 \%$ & $19.09 \%$ & $20.94 \%$ & $37.73 \%$ & 100 \\
\hline \multicolumn{6}{|c|}{ French consumption survey 2000-2001 : sample of married couples in which the husband was aged 45 to 55 years. } \\
\hline & $\begin{array}{l}\text { Husband } \\
\text { farmer }\end{array}$ & $\begin{array}{l}\text { Husband top } \\
\text { occupations }\end{array}$ & $\begin{array}{l}\text { Husband } \\
\text { White collar }\end{array}$ & $\begin{array}{l}\text { Husband } \\
\text { blue collar }\end{array}$ & Sample \\
\hline Expenditure, Euro year & 3220 & 4812 & 3909 & 2869 & 1516 \\
\hline Wealth revenue, Euro year & 3824 & 2304 & 1442 & 518 & 3807 \\
\hline Observations & 61 & 420 & 467 & 456 & 1418 \\
\hline$\%$ & $4.3 \%$ & $29.7 \%$ & $32.9 \%$ & $32.2 \%$ & $100 \%$ \\
\hline \multicolumn{6}{|c|}{ French consumption survey 2000-2001 : sample of married couples in which the husband was aged 60 to 70 years } \\
\hline & $\begin{array}{l}\text { Husband } \\
\text { farmer }\end{array}$ & $\begin{array}{l}\text { Husband top } \\
\text { occupations }\end{array}$ & $\begin{array}{l}\text { Husband } \\
\text { White collar }\end{array}$ & $\begin{array}{l}\text { Husband } \\
\text { blue collar }\end{array}$ & Sample \\
\hline Expenditure, Euro year & 2177 & 2989 & - & 2709 & 2541 \\
\hline Wealth revenue, Euro year & 3122 & 6862 & - & 670 & 2634 \\
\hline Observations & 79 & 118 & 6 & 361 & 882 \\
\hline$\%$ & $8.9 \%$ & $13.38 \%$ & - & $40.93 \%$ & $100 \%$ \\
\hline
\end{tabular}

French Time Use Survey 1998-99: sample of working age couples with both partners aged between 20 and 59 years.

\begin{tabular}{lllllll} 
& $\begin{array}{l}\text { Husband } \\
\text { farmer }\end{array}$ & $\begin{array}{l}\text { Husband top } \\
\text { occupations }\end{array}$ & $\begin{array}{l}\text { Husband } \\
\text { White collar }\end{array}$ & $\begin{array}{l}\text { Husband } \\
\text { blue collar }\end{array}$ & Sample & $\begin{array}{l}\text { Wife } \\
\text { Farmer }\end{array}$ \\
His house work hours & 3.52 & 9.06 & 12.07 & 12.16 & 10.99 & 6.45 \\
& $(5.89)$ & $(11.28)$ & $(12.30)$ & $(12.23)$ & $(12.00)$ & $(11.60)$ \\
Her house work hours & 26.32 & 13.63 & 23.96 & 26.57 & 24.88 & 28.48 \\
& $(12.94)$ & $(14.85)$ & $(14.57)$ & $(13.93)$ & $(14.42)$ & $(12.16)$ \\
His Leisure hours & 12.24 & 15.32 & 19.02 & 19.67 & 18.00 & 10.18 \\
& $(12.64)$ & $(11.94)$ & $(13.06)$ & $(13.39)$ & $(13.02)$ & $(11.67)$ \\
Her leisure hours & 11.65 & 14.67 & 15.97 & 16.44 & 15.64 & 8.74 \\
& $(9.77)$ & $(10.17)$ & $(10.60)$ & $(10.87)$ & $(10.60$ & $(8.62)$ \\
Observations & 98 & 812 & 955 & 1052 & 2919 & 51 \\
\% & $3.36 \%$ & $27.82 \%$ & $32.72 \%$ & $36.04 \%$ & $100 \%$ & $1.75 \%$ \\
\hline Source : author's calculations from the raw survey data as specified above. Unweighted statistics. \\
\hline
\end{tabular}




\begin{tabular}{|c|c|c|c|c|c|c|c|c|}
\hline \multirow[t]{3}{*}{ Table 6} & \multicolumn{8}{|c|}{ Sample descriptives by retirement status on the two sides of the age discontinuity. Men. } \\
\hline & \multicolumn{2}{|c|}{ Not Retired \& Aged $<60$} & \multicolumn{2}{|c|}{ Not Retired \& Aged $>=60$} & \multicolumn{2}{|c|}{ Retired \& Aged $<60$} & \multicolumn{2}{|c|}{ Retired \& Aged $>=60$} \\
\hline & Mean & Std. Dev. & Mean & Std. Dev. & Mean & Std. Dev. & Mean & Std. Dev. \\
\hline Divorce & 0.068 & 0.252 & 0.052 & 0.223 & 0.061 & 0.239 & 0.042 & 0.200 \\
\hline married & 0.857 & 0.350 & 0.814 & 0.389 & 0.860 & 0.347 & 0.850 & 0.357 \\
\hline Single & 0.044 & 0.205 & 0.093 & 0.290 & 0.047 & 0.213 & 0.048 & 0.215 \\
\hline Widow & 0.015 & 0.123 & 0.029 & 0.169 & 0.040 & 0.197 & 0.051 & 0.221 \\
\hline junior college & 0.052 & 0.223 & 0.048 & 0.213 & 0.041 & 0.199 & 0.023 & 0.152 \\
\hline high school & 0.091 & 0.287 & 0.095 & 0.294 & 0.084 & 0.277 & 0.065 & 0.247 \\
\hline middle tech & 0.282 & 0.450 & 0.119 & 0.324 & 0.274 & 0.446 & 0.175 & 0.379 \\
\hline middle school & 0.054 & 0.227 & 0.043 & 0.203 & 0.063 & 0.243 & 0.047 & 0.213 \\
\hline school & 0.399 & 0.489 & 0.432 & 0.495 & 0.503 & 0.500 & 0.635 & 0.481 \\
\hline Children home & 0.851 & 1.121 & 0.462 & 0.907 & 0.469 & 0.932 & 0.221 & 0.625 \\
\hline local U Rate & 9.240 & 2.427 & 9.239 & 2.369 & 9.519 & 2.429 & 9.445 & 2.429 \\
\hline sex-ratio & 0.482 & 0.011 & 0.462 & 0.013 & 0.475 & 0.011 & 0.458 & 0.013 \\
\hline Obs. & \multicolumn{2}{|l|}{84351} & \multicolumn{2}{|l|}{6520} & \multicolumn{2}{|l|}{16140} & \multicolumn{2}{|c|}{95920} \\
\hline
\end{tabular}




\begin{tabular}{|c|c|c|c|c|c|c|c|c|}
\hline \multirow[t]{3}{*}{ Table 7.} & \multicolumn{8}{|c|}{$\begin{array}{l}\text { Sample descriptives by retirement status on the two sides of the age discontinuity. } \\
\text { Male sample.Men whose father was a farmer. }\end{array}$} \\
\hline & \multicolumn{2}{|c|}{ Not Retired \& Aged<60 } & \multicolumn{2}{|c|}{ Not Retired \& Aged $>=60$} & \multicolumn{2}{|c|}{ Retired \& Aged<60 } & \multicolumn{2}{|c|}{$\begin{array}{c}\text { Retired \& Aged }>=60 \\
\text { Std. }\end{array}$} \\
\hline & Mean & Std. Dev. & Mean & Std. Dev. & Mean & Std. Dev. & Mean & Dev. \\
\hline divorce & 0.040 & 0.196 & 0.029 & 0.168 & 0.035 & 0.185 & 0.028 & 0.165 \\
\hline married & 0.867 & 0.339 & 0.758 & 0.428 & 0.868 & 0.338 & 0.843 & 0.364 \\
\hline single & 0.065 & 0.246 & 0.168 & 0.374 & 0.059 & 0.236 & 0.076 & 0.266 \\
\hline widow & 0.015 & 0.122 & 0.033 & 0.179 & 0.025 & 0.157 & 0.046 & 0.210 \\
\hline children at home & 0.960 & 1.253 & 0.559 & 1.038 & 0.580 & 1.164 & 0.269 & 0.702 \\
\hline junior college & 0.024 & 0.155 & 0.018 & 0.133 & 0.024 & 0.154 & 0.009 & 0.096 \\
\hline high school & 0.052 & 0.221 & 0.040 & 0.196 & 0.042 & 0.201 & 0.024 & 0.152 \\
\hline middle tech & 0.261 & 0.439 & 0.092 & 0.289 & 0.176 & 0.381 & 0.095 & 0.294 \\
\hline middle school & 0.036 & 0.186 & 0.030 & 0.170 & 0.042 & 0.200 & 0.022 & 0.147 \\
\hline$<$ middle school & 0.588 & 0.492 & 0.741 & 0.438 & 0.704 & 0.456 & 0.834 & 0.372 \\
\hline local U Rate & 8.951 & 2.195 & 9.034 & 2.248 & 9.068 & 2.082 & 9.055 & 2.132 \\
\hline sex-ratio & 0.481 & 0.011 & 0.461 & 0.012 & 0.474 & 0.011 & 0.458 & 0.013 \\
\hline Obs. & 17958 & & 1547 & & 3019 & & 23689 & \\
\hline
\end{tabular}


Figure 3 A. McCrary density distribution of the running variable (age)

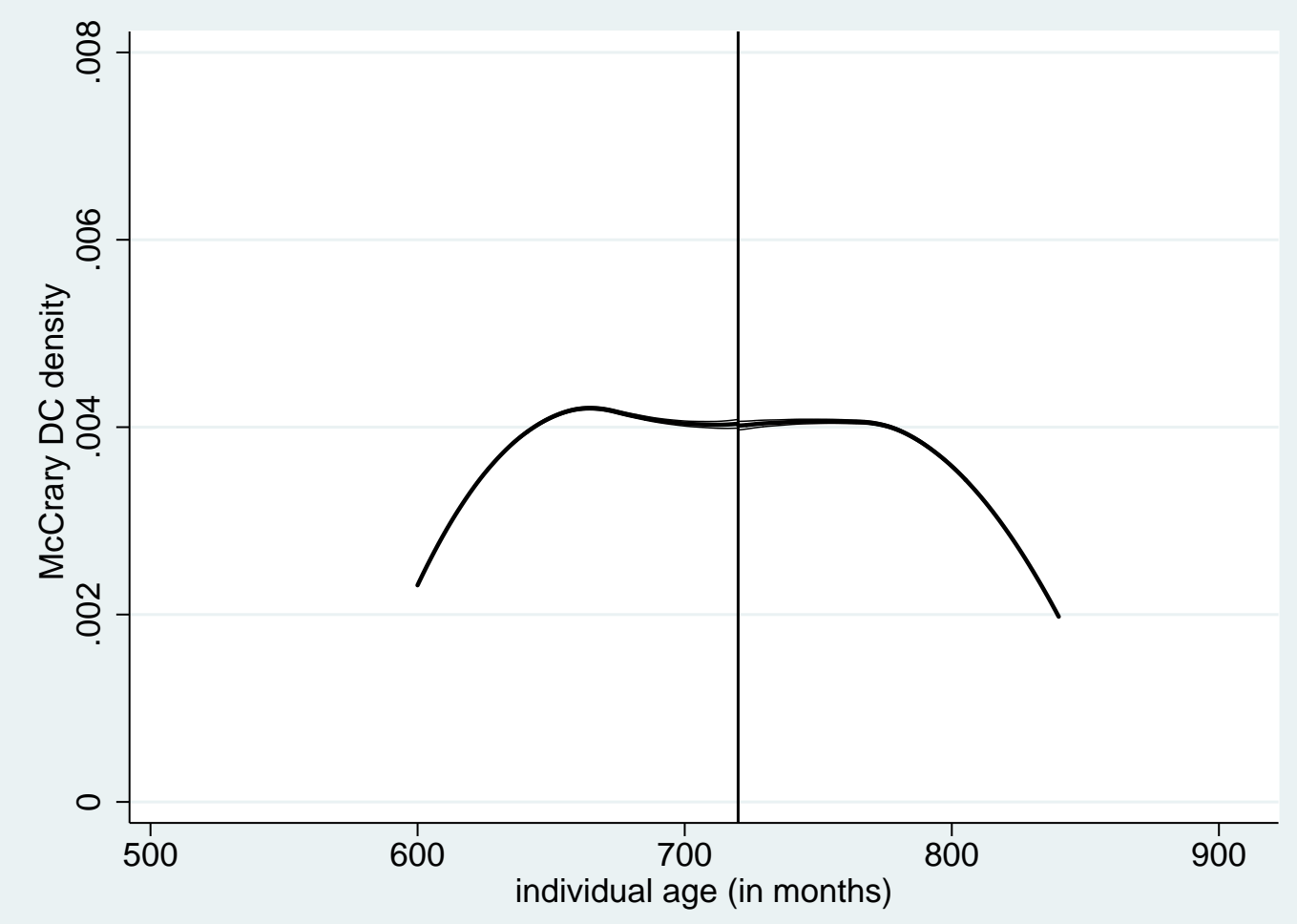


Figure $3 \mathrm{~B}$. McCrary density distribution of the running variable (age).

Subsample of individuals whose father was a farmer.

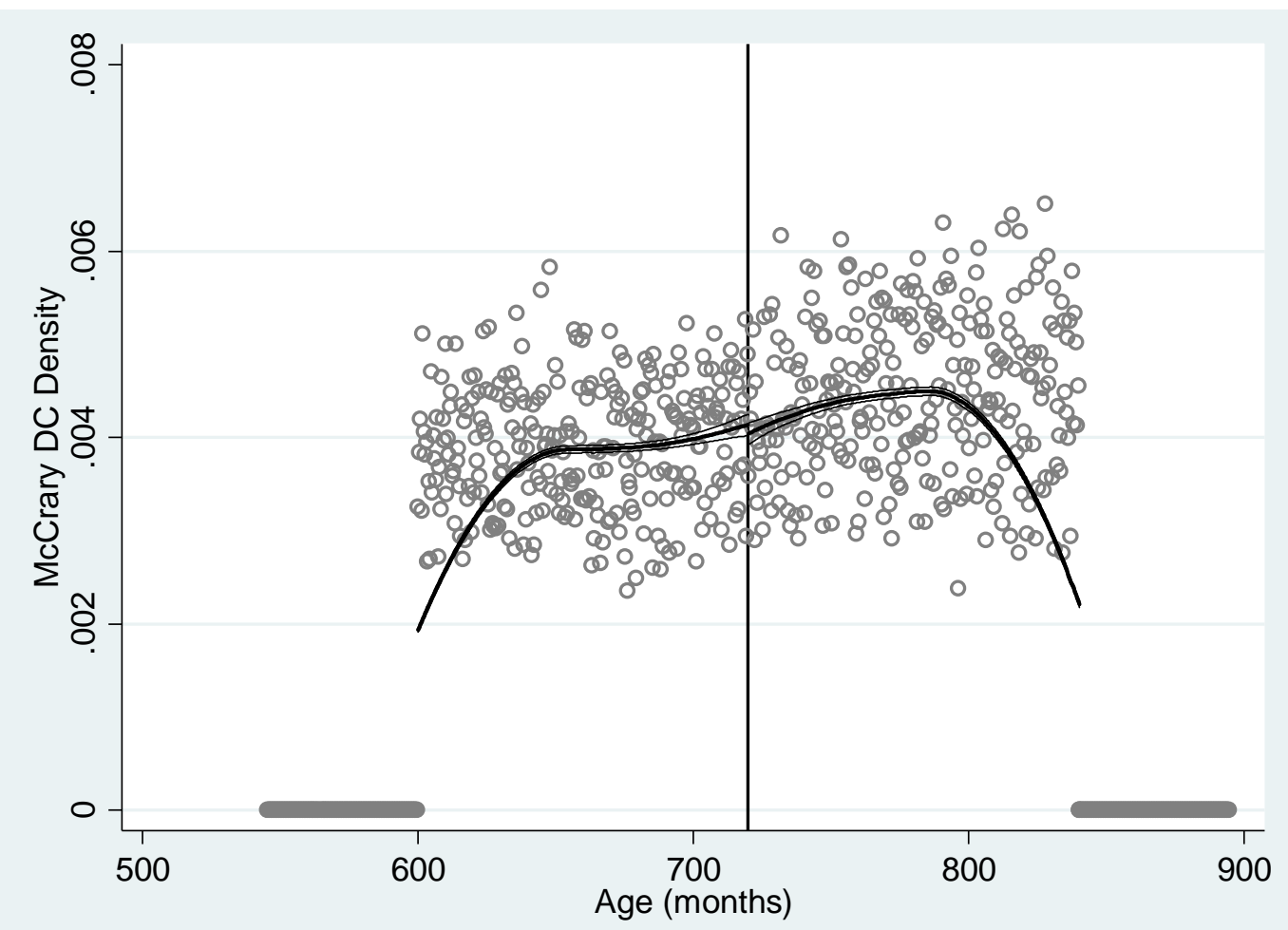


Figure 4A. Individual retirement probability: means by bins of ten months of age.
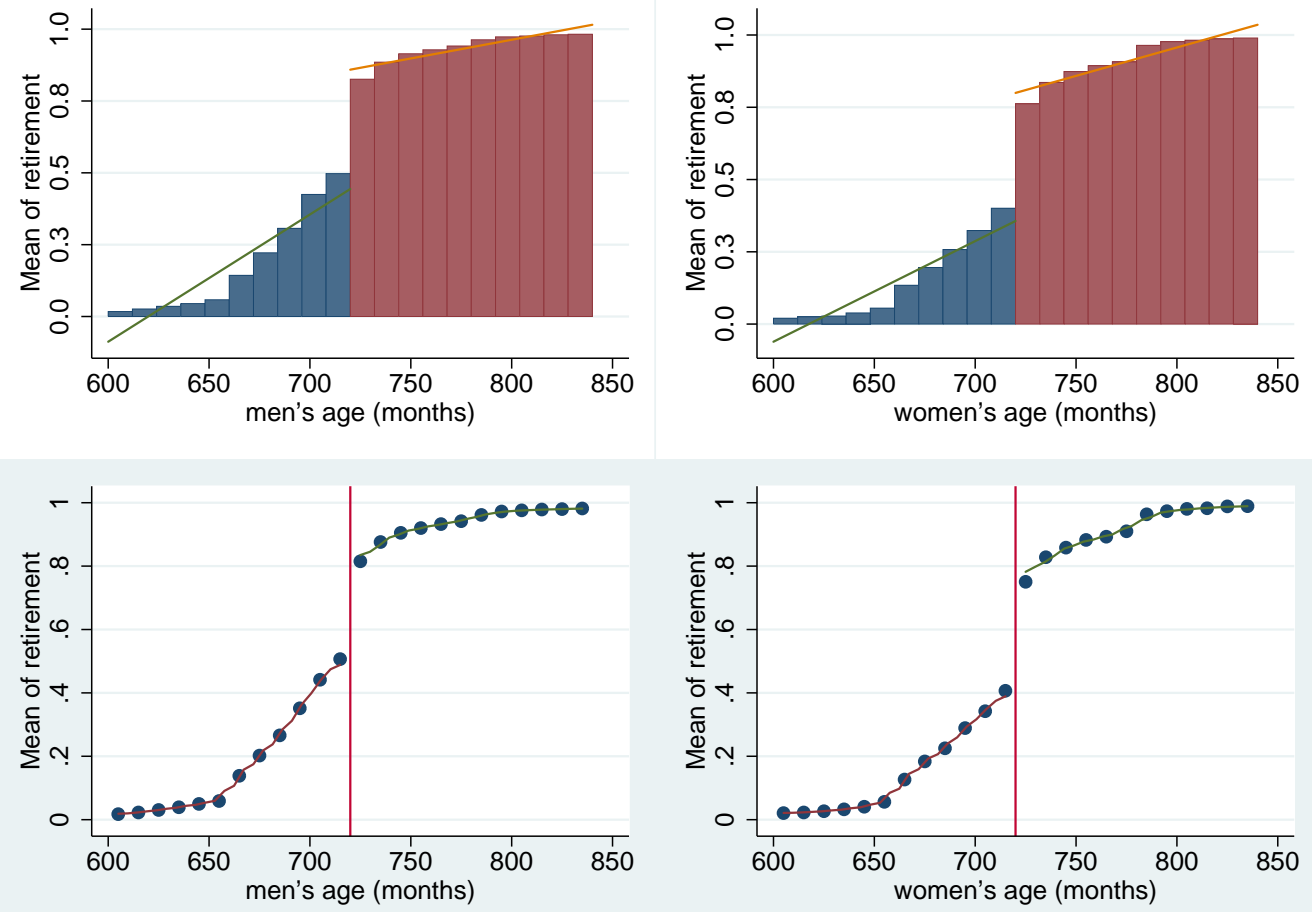
Figure 4B. Divorce rates (outcome variable): means by bins of ten months of age.
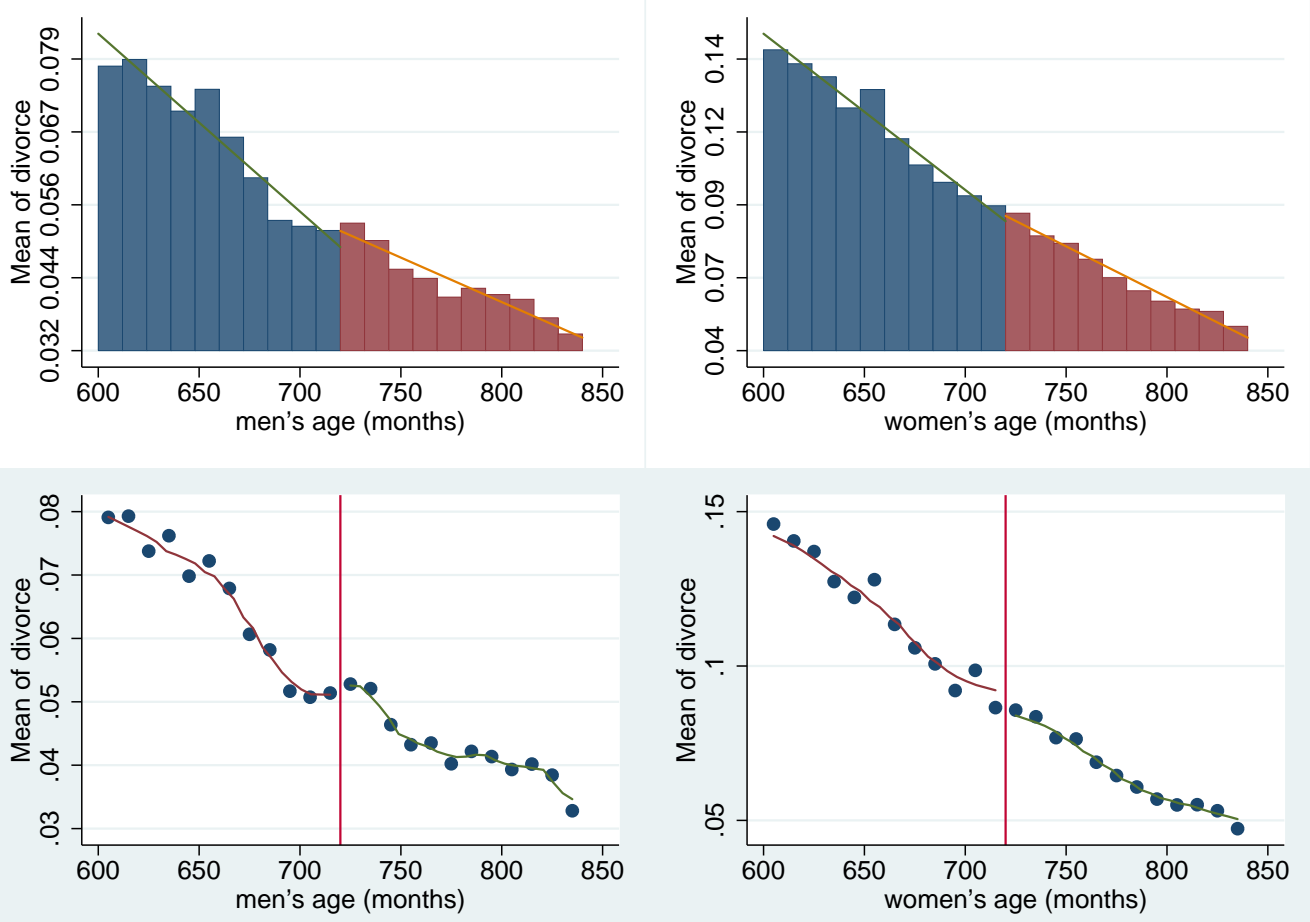
Figure 4C. Marriage rates (outcome variable): means by bins of ten months of age.
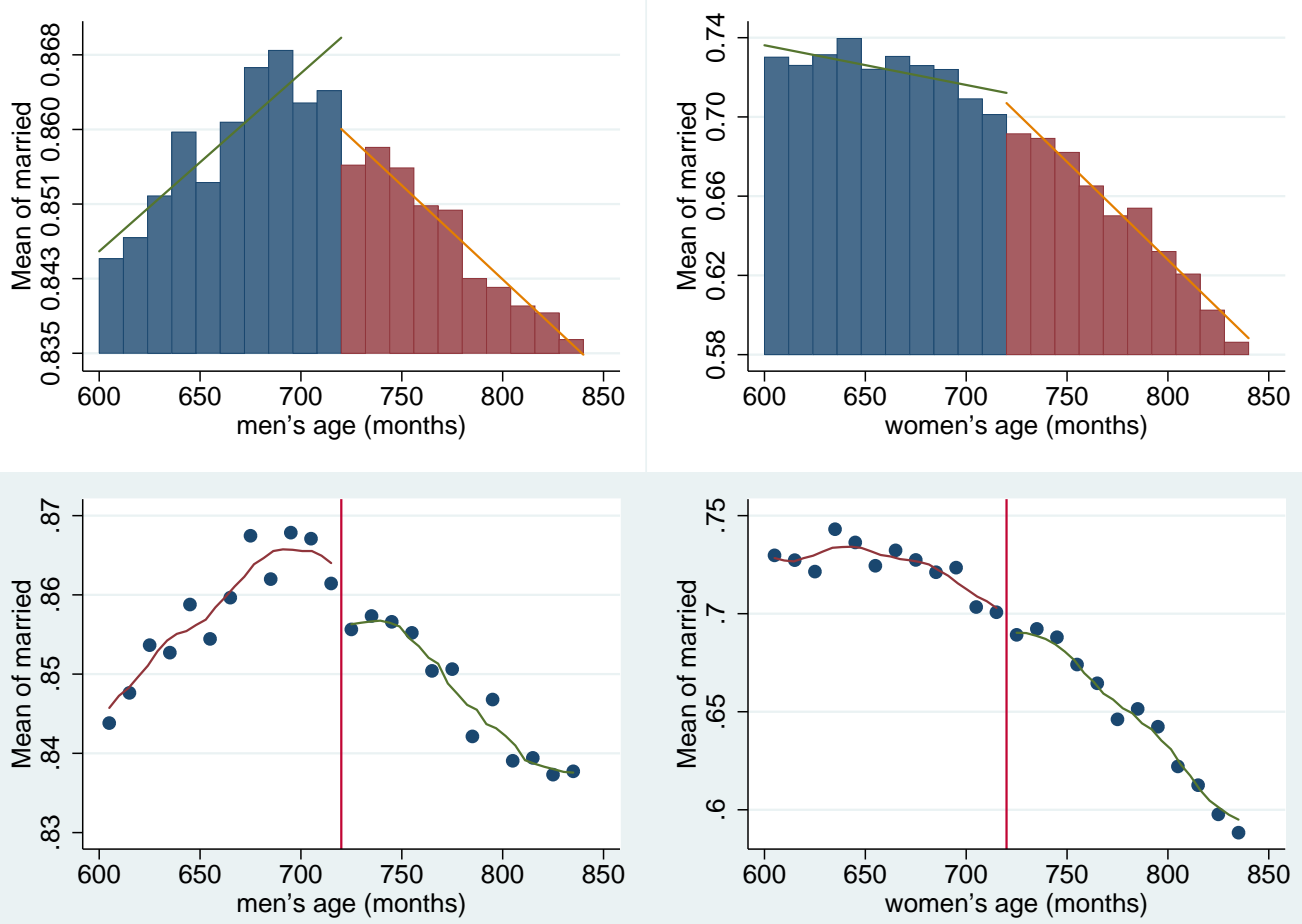
Figure 4D. Widowhood rates: means by bins of ten months of age.
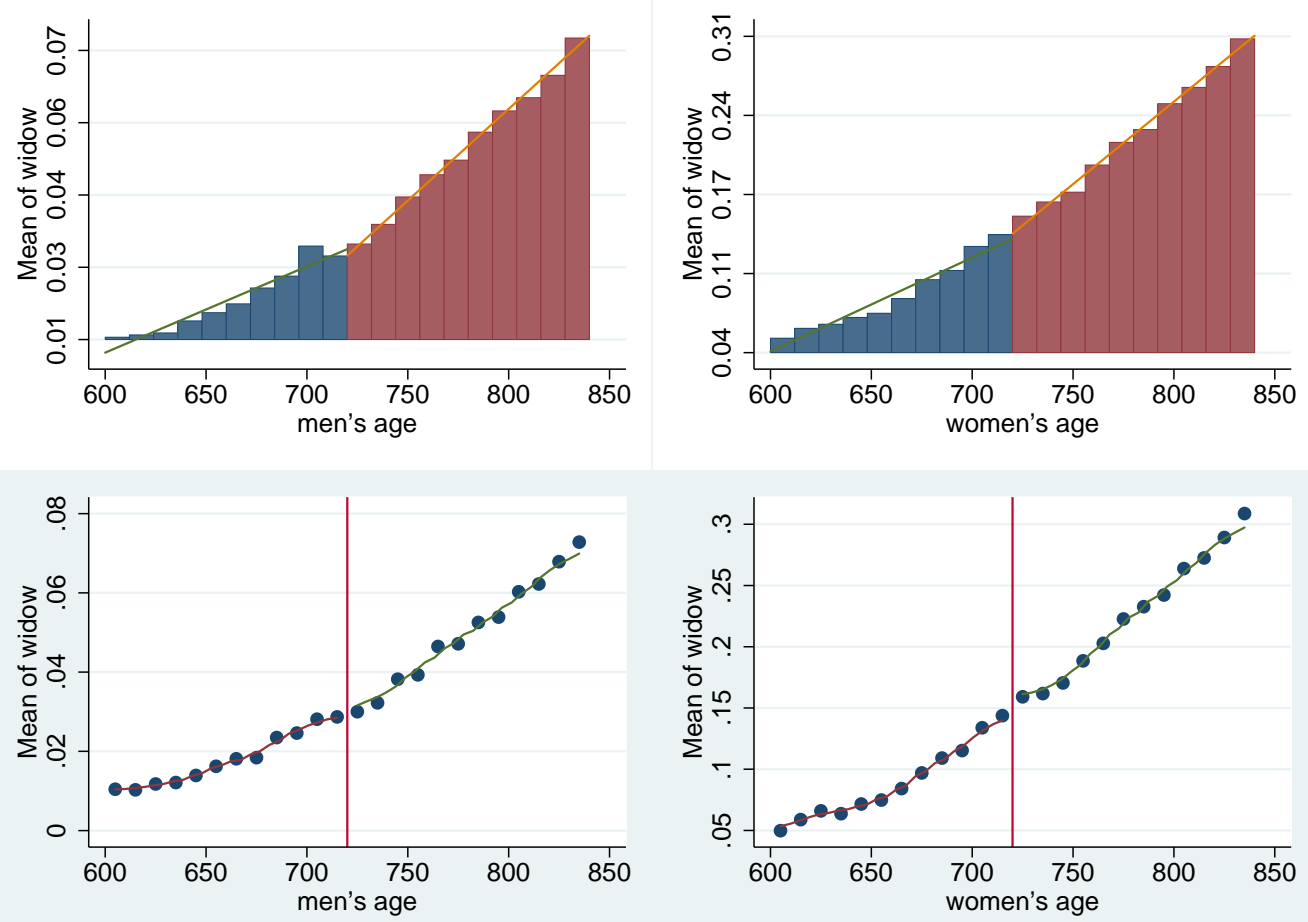
Figure $5 \mathrm{~A}$. Means of retirement by age (bins of ten months). Subsamples of men and women whose father was a farmer.
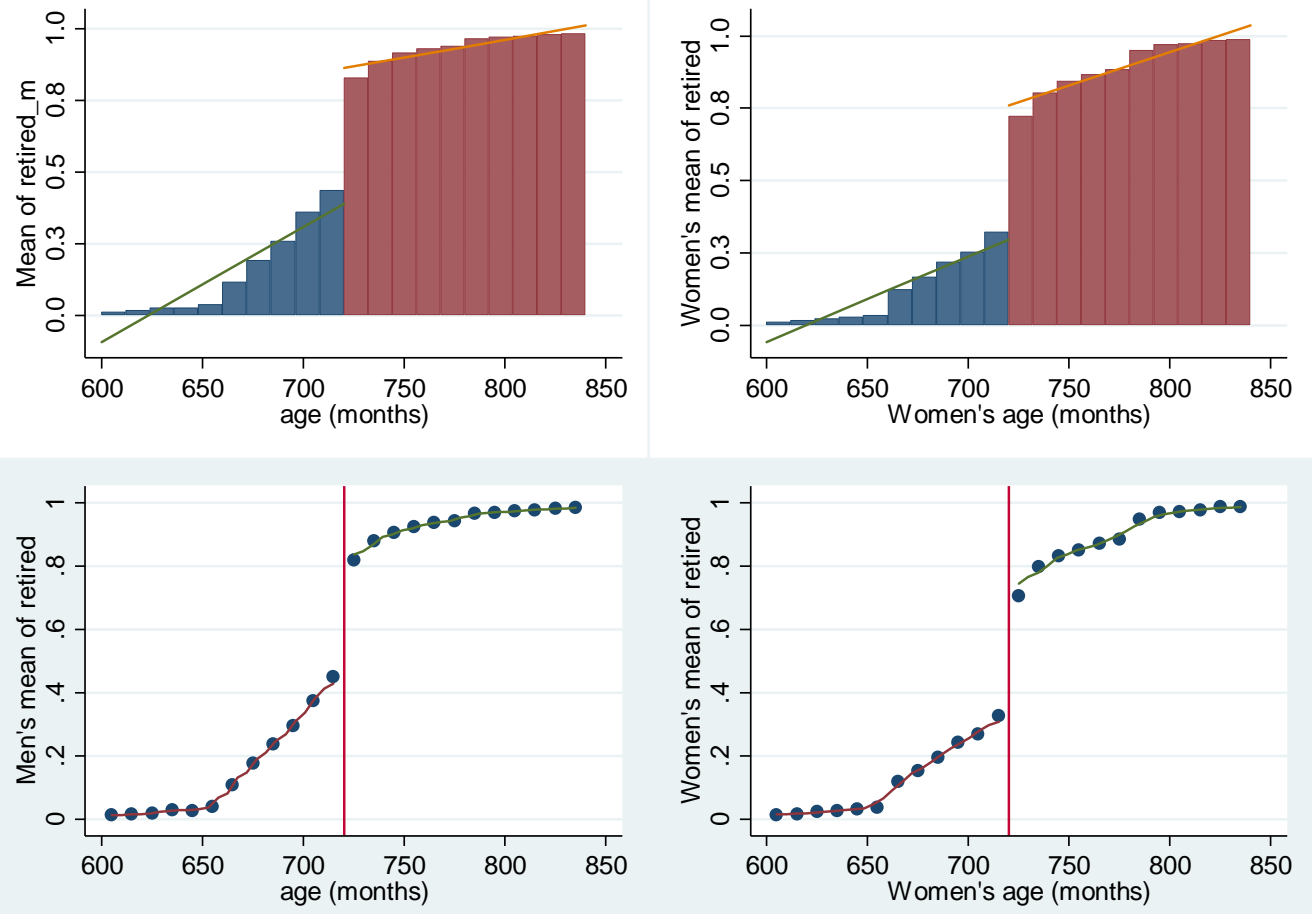
Figure $5 \mathrm{~B}$. Means of divorce by age (bins of ten months).

Subsamples of men and women whose father was a farmer.
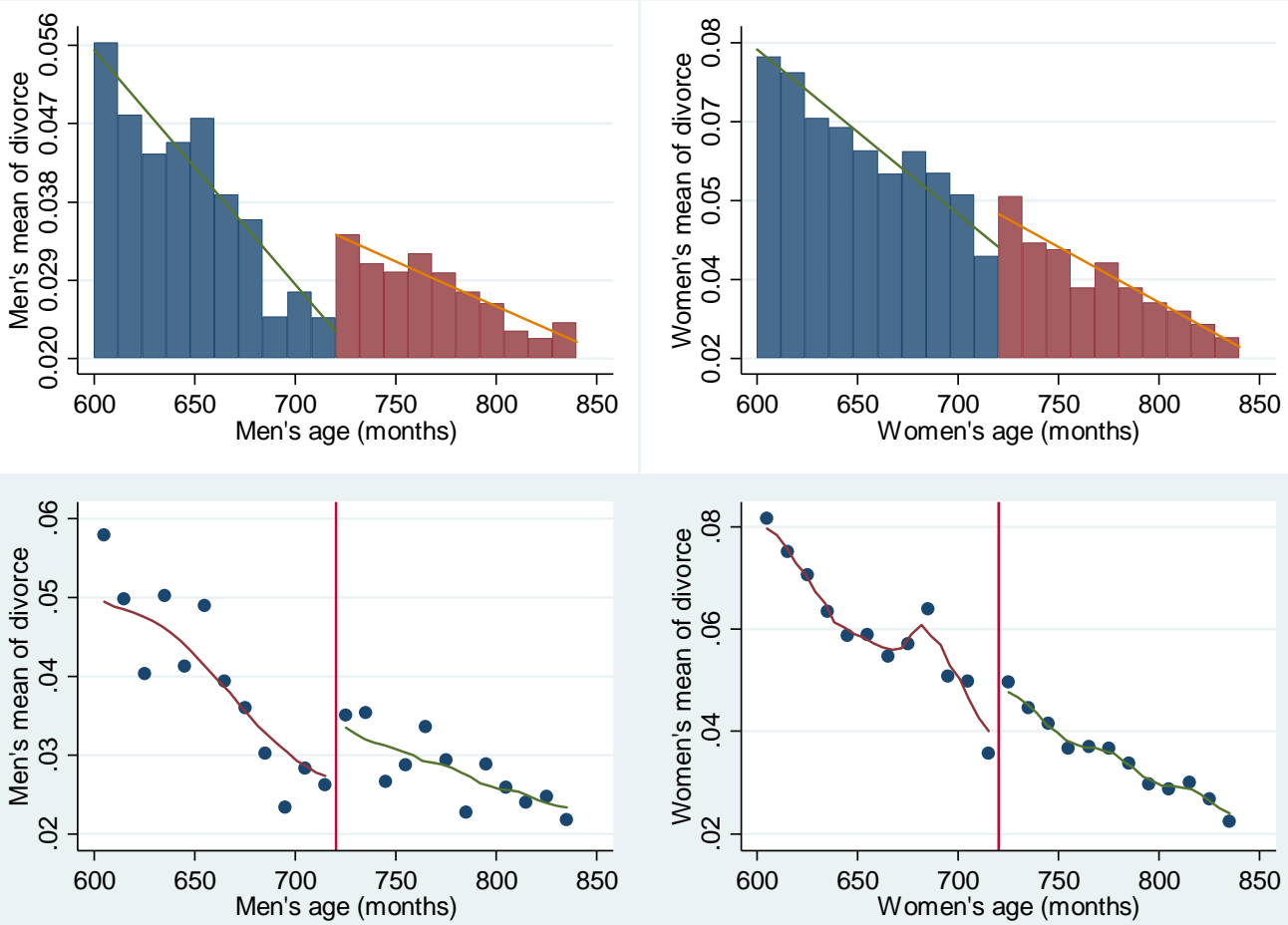
Figure $5 \mathrm{C}$. Means of marriage by age (bins of ten months).

Subsamples of men and women whose father was a farmer.
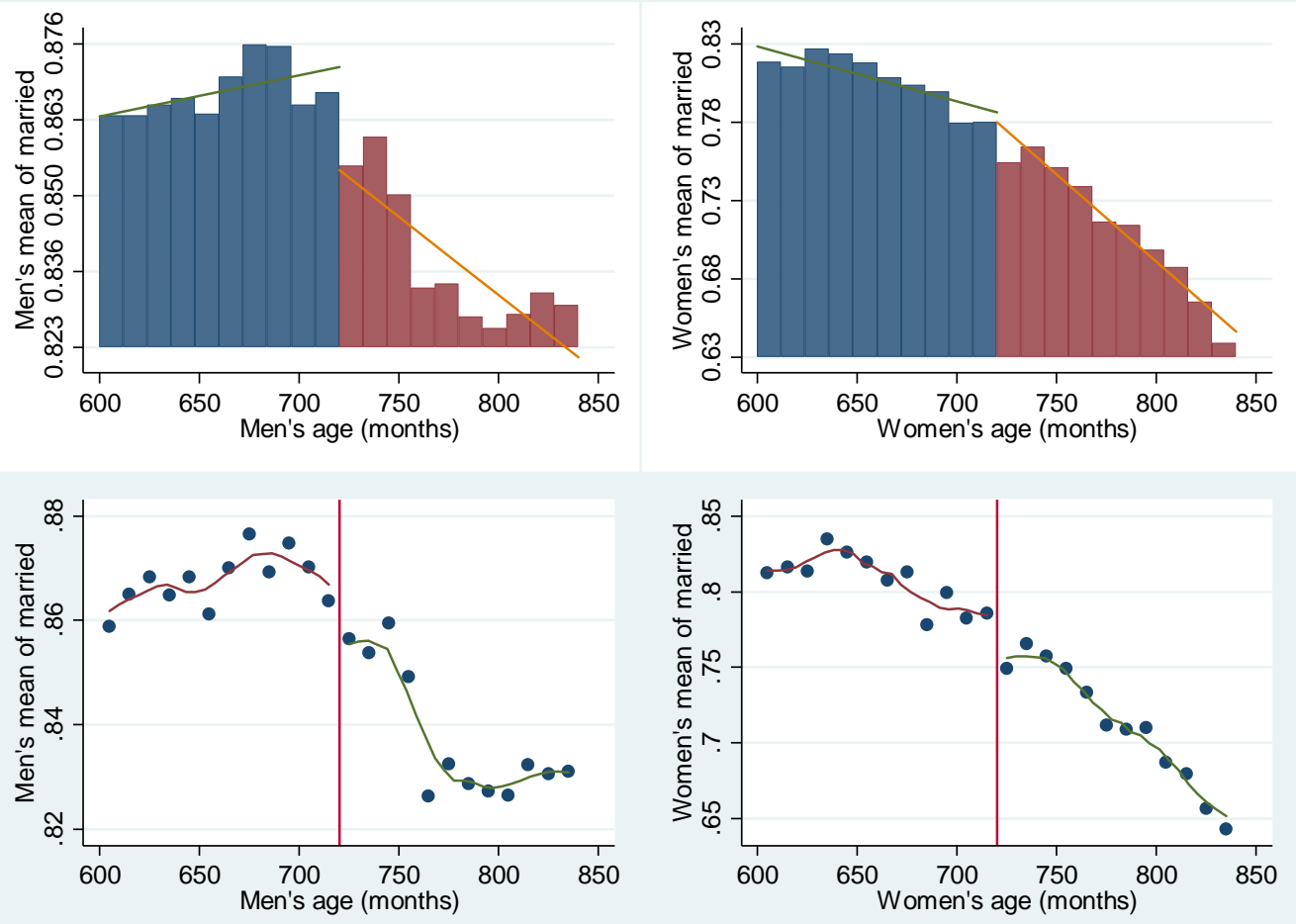
Figure $5 \mathrm{D}$. Means of widowhood by age (bins of ten months). Subsamples of men and women whose father was a farmer.
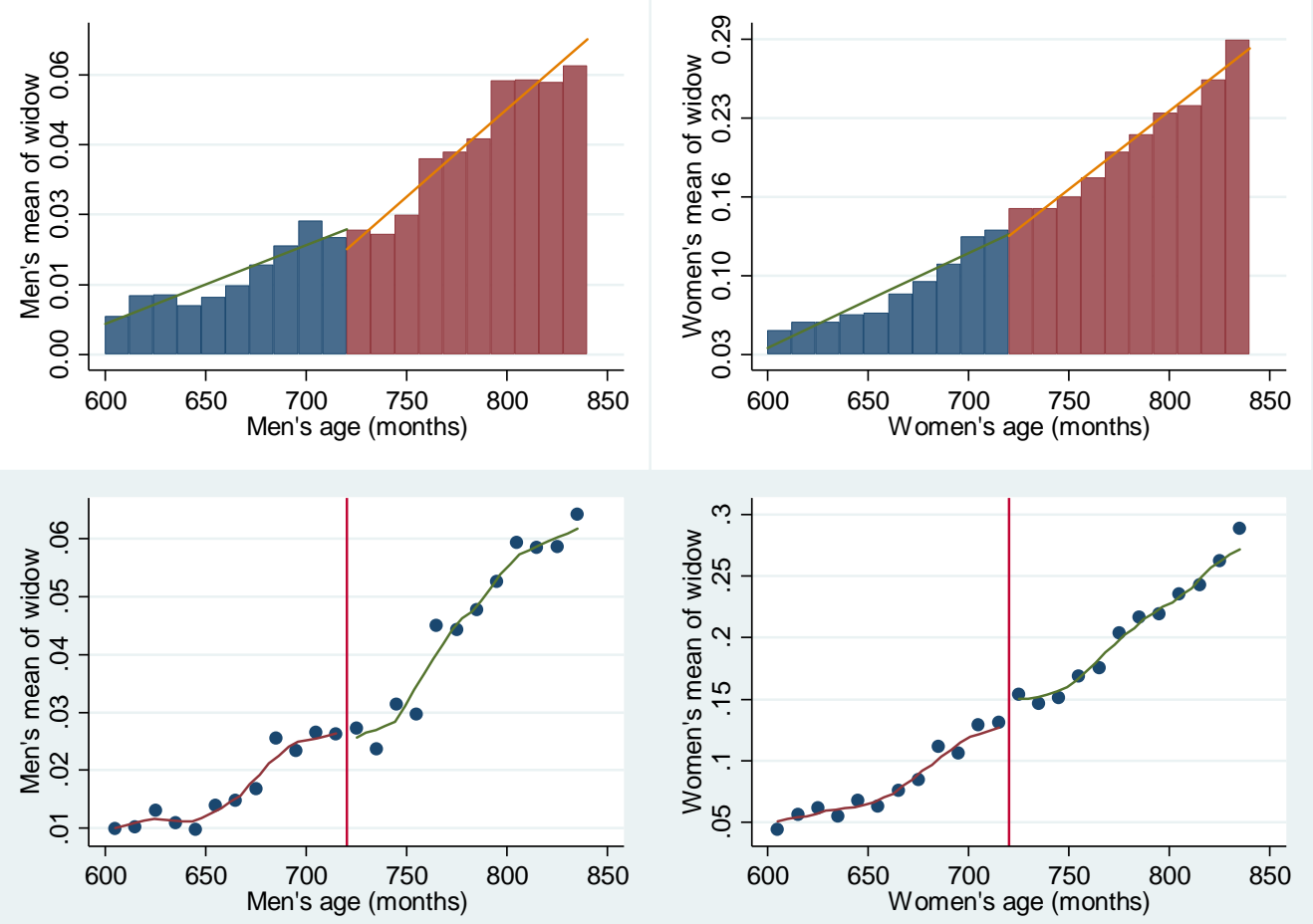
Figure 6. Predicted divorce rates as a function of the Z's: means by bins of ten months of age.
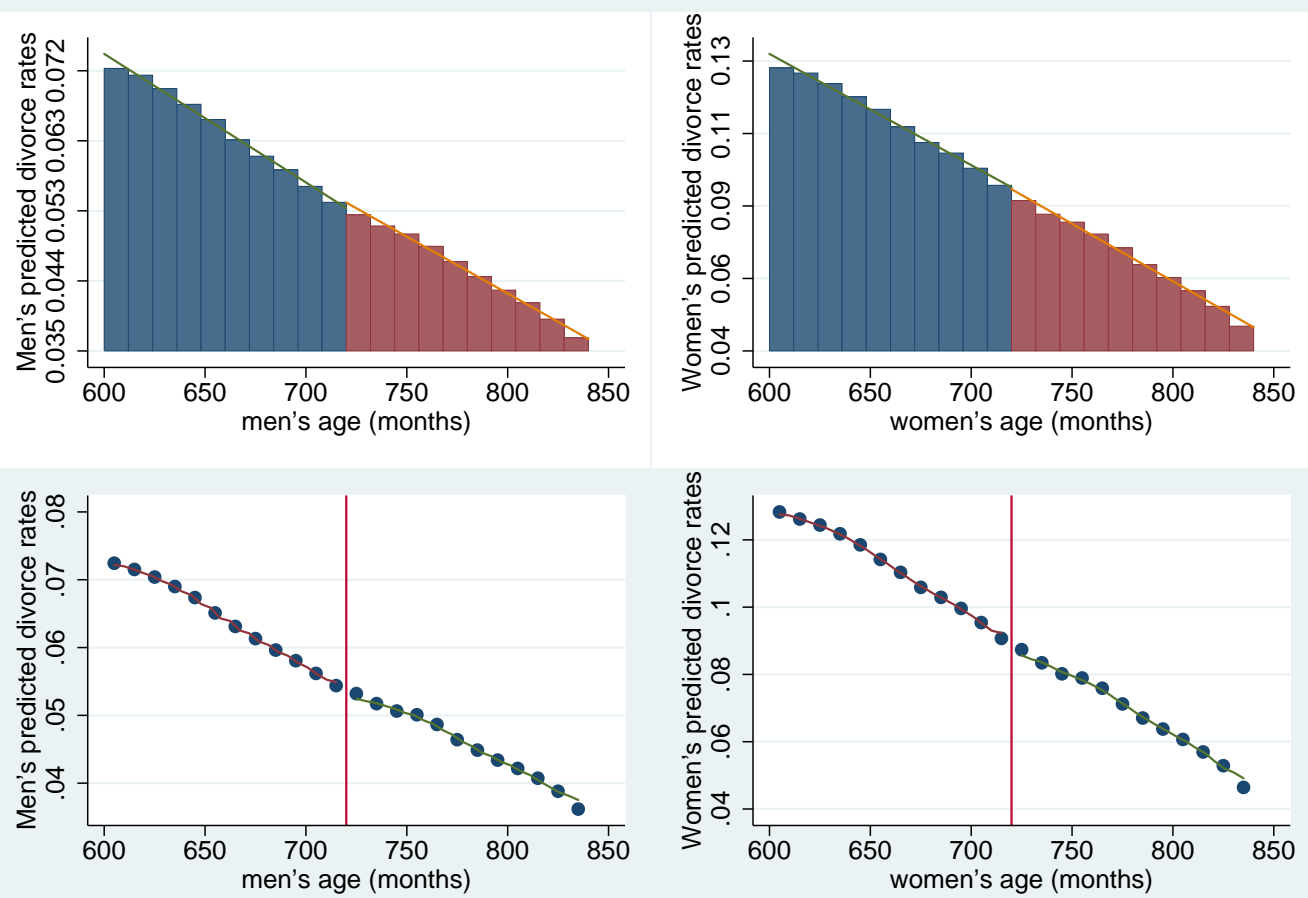

Predicted divorce rates as a function of the $Z$ covariates (see Section 2). 
Table 8. Results of estimation for men.

(Selected coefficient estimates, standard errors in brackets).

\begin{tabular}{|c|c|c|c|c|c|c|}
\hline \multirow[t]{2}{*}{ Men } & $(1)$ & $(2)$ & (3) & $(4)$ & $(5)$ & $(6)$ \\
\hline & \multicolumn{6}{|c|}{ IV, First stage equation for retirement } \\
\hline Mean retirement, age 59 to $<60$ & 0.496 & 0.496 & 0.496 & 0.496 & 0.496 & 0.496 \\
\hline \multirow[t]{3}{*}{ Age 60 and above coefficient } & $0.236 * * *$ & $0.234 * * *$ & $0.223 * * *$ & $0.221 * * *$ & $0.236 * * *$ & $0.234 * * *$ \\
\hline & $(0.010)$ & $(0.010)$ & $(0.008)$ & $(0.008)$ & $(0.006)$ & $(0.005)$ \\
\hline & \multicolumn{6}{|c|}{ IV, Outcome variable: divorce rate } \\
\hline Mean divorce, age 59 to $<60$ & 0.051 & 0.051 & 0.051 & 0.051 & 0.051 & 0.051 \\
\hline \multirow[t]{2}{*}{ Retirement coefficient } & 0.008 & 0.014 & 0.028 & $0.034 *$ & $0.033 * *$ & $0.035^{* *}$ \\
\hline & $(0.021)$ & $(0.021)$ & $(0.018)$ & $(0.018)$ & $(0.013)$ & $(0.013)$ \\
\hline Including Zs & NO & YES & NO & YES & NO & YES \\
\hline Quartic Age polynomial & YES & YES & NO & NO & NO & NO \\
\hline Cubic age polynomial & NO & NO & YES & YES & NO & $\mathrm{NO}$ \\
\hline Quadratic Age polynomial & NO & NO & NO & NO & YES & YES \\
\hline Observations number & 202931 & 202606 & 202931 & 202606 & 202931 & 202606 \\
\hline \multirow[t]{2}{*}{ Men } & (7) & $(8)$ & (9) & $(10)$ & (11) & $(12)$ \\
\hline & \multicolumn{6}{|c|}{ IV, First stage equation for retirement } \\
\hline Mean retirement, age 59 to $<60$ & 0.496 & 0.496 & 0.496 & 0.496 & 0.496 & 0.496 \\
\hline \multirow[t]{3}{*}{ Age 60 and above coefficient } & $0.215 * * *$ & $0.214 * * *$ & $0.193 * * *$ & $0.193 * * *$ & $0.238 * * *$ & $0.236 * * *$ \\
\hline & $(0.011)$ & $(0.011)$ & $(0.013)$ & $(0.013)$ & $(0.010)$ & $(0.010)$ \\
\hline & \multicolumn{6}{|c|}{ IV, Outcome variable: divorce rate } \\
\hline Mean divorce, age 59 to $<60$ & 0.051 & 0.051 & 0.051 & 0.051 & 0.051 & 0.051 \\
\hline \multirow[t]{2}{*}{ Retirement coefficient } & -0.0010 & 0.006 & -0.002 & 0.005 & 0.010 & 0.015 \\
\hline & $(0.026)$ & $(0.026)$ & $(0.033)$ & $(0.033)$ & $(0.021)$ & $(0.021)$ \\
\hline Including Zs & NO & YES & NO & YES & NO & YES \\
\hline Dropping those aged 720 months & $\mathrm{NO}$ & $\mathrm{NO}$ & $\mathrm{NO}$ & $\mathrm{NO}$ & YES & YES \\
\hline Sample age 52 to 68 years & YES & YES & NO & NO & NO & NO \\
\hline Sample age 54 to 66 years & $\mathrm{NO}$ & NO & YES & YES & $\mathrm{NO}$ & $\mathrm{NO}$ \\
\hline Observations number & 159676 & 159411 & 117776 & 117566 & 202886 & 202561 \\
\hline
\end{tabular}


Table 9. Results of estimation for women.

(Selected coefficient estimates, standard errors in brackets).

\begin{tabular}{|c|c|c|c|c|c|c|}
\hline \multirow[t]{2}{*}{ Women. } & $(1)$ & $(2)$ & (3) & $(4)$ & $(5)$ & $(6)$ \\
\hline & \multicolumn{6}{|c|}{ IV, First stage equation for retirement } \\
\hline Mean retirement, age 59 to $<60$ & 0.401 & 0.401 & 0.401 & 0.401 & 0.401 & 0.401 \\
\hline \multirow[t]{3}{*}{ Age 60 and above coefficient } & $0.293 * * *$ & $0.293 * * *$ & $0.294 * * *$ & $0.294 * * *$ & $0.284 * * *$ & $0.284 * * *$ \\
\hline & $(0.012)$ & $(0.012)$ & $(0.009)$ & $(0.009)$ & $(0.007)$ & $(0.007)$ \\
\hline & \multicolumn{6}{|c|}{ IV, Outcome variable: divorce rate } \\
\hline Mean divorce, age 59 to $<60$ & 0.090 & 0.090 & 0.090 & 0.090 & 0.090 & 0.090 \\
\hline \multirow[t]{2}{*}{ Retirement coefficient } & -0.020 & -0.018 & 0.003 & 0.009 & 0.018 & 0.023 \\
\hline & $(0.026)$ & $(0.025)$ & $(0.020)$ & $(0.020)$ & $(0.016)$ & $(0.016)$ \\
\hline Including Zs & NO & YES & NO & YES & NO & YES \\
\hline Quartic Age polynomial & YES & YES & NO & NO & NO & $\mathrm{NO}$ \\
\hline Cubic age polynomial & NO & NO & YES & YES & NO & NO \\
\hline Quadratic Age polynomial & NO & NO & NO & NO & YES & YES \\
\hline Observations number & 166162 & 165907 & 166162 & 165907 & 166162 & 165907 \\
\hline \multirow[t]{2}{*}{ Women } & (7) & $(8)$ & (9) & $(10)$ & (11) & $(12)$ \\
\hline & \multicolumn{6}{|c|}{ IV, First stage equation for retirement } \\
\hline Mean retirement, age 59 to $<60$ & 0.401 & 0.401 & 0.401 & 0.401 & 0.401 & 0.401 \\
\hline \multirow[t]{3}{*}{ Age 60 and above coefficient } & $0.254 * * *$ & $0.255^{* * *}$ & $0.229 * * *$ & $0.231 * * *$ & $0.298 * * *$ & $0.298 * * *$ \\
\hline & $(0.014)$ & $(0.013)$ & $(0.016)$ & $(0.016)$ & $(0.012)$ & $(0.012)$ \\
\hline & \multicolumn{6}{|c|}{ IV, Outcome variable: divorce rate } \\
\hline Mean divorce, age 59 to $<60$ & 0.090 & 0.090 & 0.090 & 0.090 & 0.090 & 0.090 \\
\hline \multirow[t]{2}{*}{ Retirement coefficient } & -0.030 & -0.031 & -0.012 & -0.019 & -0.018 & -0.016 \\
\hline & $(0.033)$ & $(0.033)$ & $(0.043)$ & $(0.042)$ & $(0.026)$ & $(0.025)$ \\
\hline Including Zs & NO & YES & NO & YES & NO & YES \\
\hline Dropping those aged 720 months & NO & NO & NO & NO & YES & YES \\
\hline Sample age 52 to 68 years & YES & YES & NO & NO & NO & NO \\
\hline Sample age 54 to 66 years & NO & NO & YES & YES & NO & $\mathrm{NO}$ \\
\hline Observations & 128174 & 127976 & 91828 & 91690 & 166129 & 165874 \\
\hline
\end{tabular}


Table 10. Results of estimation for the subsample of men whose father was a farmer.
(1)
(2)
(3)
(4)
(5)
(6)

IV, First stage equation for retirement

Mean retirement, age 59 to $<60$

Age 60 and above coefficient

$0.30 * * *$

$0.297 * * *$

$0.296 * * *$

0.437

0.437

0.437

$(0.021)$

(0.021)

(0.016)

$0.295 * * *$

$0.310 * * *$

$0.310 * * *$

IV, Outcome variable: Divorce rate

Mean divorce, age 59 to $<60$

0.025

0.025

0.025

(0.016)

(0.011)

Retirement coefficient

$0.045^{*}$

$0.049 *$

$0.042 * *$

0.025

0.025

0.025

(0.027)

(0.027)

(0.022)

$0.047 * *$

$0.043 * *$

$0.042 * *$

Including Zs

NO

YES

NO

(0.022)

(0.016)

(0.016)

Quartic Age polynomial

YES

YES

NO

YES

NO

YES

Cubic age polynomial

NO NO

YES

NO

NO

NO

Quadratic Age polynomial

NO NO

NO

YES

$\mathrm{NO}$

$\mathrm{NO}$

Observations

46213

46121

46213

(1)

(7)

(8)

(9)

(10)

YES

YES

Men's main sample

IV, First stage equation for retirement

Mean retirement, age 59 to $<60$

$0.437-0.437$

$0.273 * * *$

$0.270 * * *$

$0.247 * * *$

0.437

46213

46121

Age 60 and above coefficient

(0.024)

$(0.023)$

(0.028)

\section{$0.246^{* * *}$}

0.437

(0.027)

(0.021)

IV, Outcome variable: Divorce rate

Mean divorce, age 59 to $<60$

0.025

0.025

0.025

$0.063 * *$

$0.069 * *$

$0.105 * *$

0.025

0.025

Retirement coefficient

(0.032)

(0.033)

(0.042)

NO

$0.111 * * *$

$0.045^{*}$

0.050 *

Including Zs

NO

YES

YES

(0.042)

(0.026)

(0.027)

YES

YES

NO

YES

$\mathrm{NO}$

YES

NO NO

YES

YES

YES

Dropping those aged 720 months

Sample age 52 to 68 years

YES

YES

NO

$\mathrm{NO}$

YES

YES

Sample age 54 to 66 years

NO

NO

YES

NO

NO

$\mathrm{NO}$

36847

36763

27425

YES

NO

NO

The IV model is estimated by two stages least squares with robust standard errors. The first stage regressors include a dummy for being aged 720 months and above, a polynomial in age, and full interactions of the two. The outcome equation includes a polynomial in age, and full interactions with the dummy for being aged 720 months and above. The $\mathrm{Z}$ variables include year and local area fixed effects, the individual sex ratio, the local unemployment rate a year before the survey, education dummies, and number of children still living at home.

Note: $* * *$ denotes statistical significance at the $1 \%$ level; ** at the $5 \%$ level and $*$ at the $10 \%$ level. 
Table 11. Results of estimation for women whose father was a farmer.
(1)
(2)
(3)
(4)
(5)
(6)

IV, First stage equation for retirement

Mean retirement, age 59 to $<60$

$\begin{array}{lll}0.324 & 0.324 & 0.324\end{array}$

$0.329 * * *$

$0.323 * * *$

$0.340^{* * *}$

0.324

0.324

0.324

Age 60 and above

$(0.025)$

(0.024)

$(0.019)$

$0.340^{* * *}$

$0.329 * * *$

$0.328^{* * *}$

IV, Outcome variable: divorce rate

Mean divorce, age 59 to $<60$

0.039

$0.039 \quad 0.039$

$(0.019)$

$(0.014)$

$(0.014)$

Retirement

$0.068 *$

$0.068 *$

$0.057 * *$

0.039

0.039

0.039

Including Zs

(0.036)

(0.036)

(0.027)

$0.058 * *$

0.014

0.017

Including Zs

NO

YES

NO

(0.027)

(0.020)

(0.020)

Quartic Age polynomial

YES

YES

NO

YES

NO

YES

Cubic age polynomial

NO NO

YES

NO

NO

NO

Quadratic Age polynomial

NO NO

NO

YES

NO

NO

Observations

38477

38385

38477

NO

YES

YES

(7)

(8)

(9)

(10)

38477

38385

IV, First stage equation for retirement

Mean retirement, age 59 to $<60$
Age 60 and above

$\begin{array}{lll}0.324 & 0.324 & 0.324\end{array}$

$0.268 * * *$

$0.269 * * *$

$0.230 * * *$

(11)

(12)

(0.028)

(0.028)

(0.033)

0.324

0.324

0.324

IV, Outcome variable: divorce rate

Mean divorce, age 59 to $<60$

0.039

0.039

0.039

$0.232 * * *$

$0.0329 * * *$

$0.328 * * *$

Retirement

$0.082 *$

$0.082 *$

0.098

(0.032)

(0.025)

(0.024)

.

Including Zs

(0.049)

(0.048)

(0.066)

0.039

0.039

0.039

NO

YES

NO

0.102

0.068*

$0.068 *$

Dropping those aged 720 months

NO

NO

NO

(0.066)

$(0.035)$

$(0.035)$

Sample age 52 to 68 years

YES

YES

NO

YES

NO

YES

Sample age 54 to 66 years

NO

NO

YES

NO

YES

YES

Observations

29987

29920

21716

NO

NO

$\mathrm{NO}$

The IV model is estimated

YES

NO

$\mathrm{NO}$ with the unemployment rate a year before the survey, education dummies, and number of children still living at home.

Note: $* * *$ denotes statistical significance at the $1 \%$ level; ** at the $5 \%$ level and $*$ at the $10 \%$ level. 
Table 12. Results of estimation. More robustness checks.

Including birth cohort dummies/ dropping observations from 2000s or early 1990 waves

\begin{tabular}{|c|c|c|c|c|c|c|}
\hline \multirow[t]{2}{*}{ Father Farmer sample } & Men & Women & Men & Women & Men & Women \\
\hline & (1) & (2) & (3) & (4) & $(5)$ & (6) \\
\hline & \multicolumn{6}{|c|}{ IV, First stage equation for retirement } \\
\hline Mean retirement, age 59 to $<60$ & 0.437 & 0.324 & 0.437 & 0.321 & 0.461 & 0.351 \\
\hline \multirow[t]{3}{*}{ Age 60 and above } & $0.299 * * *$ & $0.324 * * *$ & $0.306 * * *$ & $0.333 * * *$ & $0.303 * * *$ & 0.329 \\
\hline & $(0.021)$ & $(0.024)$ & $(0.023)$ & $(0.027)$ & $(0.023)$ & $(0.028)$ \\
\hline & \multicolumn{6}{|c|}{ IV, Outcome variable: divorce rate } \\
\hline Mean divorce, age 59 to $<60$ & 0.025 & 0.039 & 0.023 & 0.038 & 0.028 & 0.046 \\
\hline \multirow[t]{2}{*}{ Retirement } & $0.049 *$ & $0.067^{*}$ & $0.046^{*}$ & 0.049 & $0.064 *$ & 0.068 \\
\hline & $(0.027)$ & $(0.035)$ & $(0.027)$ & $(0.035)$ & $(0.033)$ & $(0.042)$ \\
\hline Including Zs & YES & YES & YES & YES & YES & YES \\
\hline Quartic Age polynomial & YES & YES & YES & YES & YES & YES \\
\hline Including Birth Cohort Dummies & YES & YES & NO & NO & $\mathrm{NO}$ & NO \\
\hline Dropping years 2000, 2001, 2002 & NO & NO & YES & YES & NO & NO \\
\hline Dropping years 1990, 1991, 1992 & NO & NO & NO & NO & YES & YES \\
\hline Observations & 46121 & 38385 & 35930 & 29815 & 35357 & 29561 \\
\hline
\end{tabular}


Table 13. Results of estimation by respondent's father occupation.

(Selected coefficient estimates. Standard errors in brackets).

\begin{tabular}{|c|c|c|c|c|}
\hline \multirow[t]{3}{*}{ Men } & (1) & $(2)$ & (3) & (4) \\
\hline & $\begin{array}{l}\text { Fathers' } \\
\text { farmer }\end{array}$ & $\begin{array}{l}\text { Fathers' top } \\
\text { occupations }\end{array}$ & $\begin{array}{l}\text { Father's White } \\
\text { collar }\end{array}$ & $\begin{array}{l}\text { Father's Blue } \\
\text { collar }\end{array}$ \\
\hline & IV & \multicolumn{3}{|c|}{ First stage equation for retirement } \\
\hline Mean retirement, age 59 to $<60$ & 0.437 & 0.353 & 0.527 & 0.596 \\
\hline \multirow[t]{3}{*}{ Age 60 and above coefficient } & $0.297 * * *$ & $0.215^{* * *}$ & $0.213 * * *$ & $0.228 * * *$ \\
\hline & $(0.021)$ & $(0.024)$ & $(0.022)$ & $(0.015)$ \\
\hline & IV & \multicolumn{3}{|c|}{ Outcome variable: divorce rate } \\
\hline${ }^{2}$ Mean divorce, age 59 to $<60$ & 0.025 & 0.069 & 0.065 & 0.051 \\
\hline \multirow[t]{2}{*}{ Retirement coefficient } & $0.049 *$ & -0.018 & -0.037 & 0.034 \\
\hline & $(0.027)$ & $(0.06)$ & $(0.060)$ & $(0.037)$ \\
\hline Including Zs & YES & YES & YES & YES \\
\hline Observations & 46121 & 38820 & 38190 & 71555 \\
\hline \multirow[t]{3}{*}{ Women } & $(5)$ & $(6)$ & (7) & (8) \\
\hline & $\begin{array}{l}\text { Fathers' } \\
\text { farmer }\end{array}$ & $\begin{array}{l}\text { Fathers' top } \\
\text { occupations }\end{array}$ & $\begin{array}{l}\text { Father's White } \\
\text { collar }\end{array}$ & $\begin{array}{l}\text { Father's Blue } \\
\text { collar }\end{array}$ \\
\hline & IV & \multicolumn{3}{|c|}{ First stage equation for retirement } \\
\hline Mean retirement, age 59 to $<60$ & 0.324 & 0.394 & 0.494 & 0.438 \\
\hline \multirow[t]{3}{*}{ Age 60 and above coefficient } & $0.323 * * *$ & $0.210 * * *$ & $0.304 * * *$ & $0.305^{* * *}$ \\
\hline & $(0.024)$ & $(0.028)$ & $(0.026)$ & $(0.020)$ \\
\hline & IV & \multicolumn{3}{|c|}{ Outcome variable: divorce rate } \\
\hline Mean divorce, age 59 to $<60$ & 0.039 & 0.117 & 0.114 & 0.095 \\
\hline \multirow[t]{2}{*}{ Retirement coefficient } & $0.068^{*}$ & -0.080 & -0.020 & $-0.086^{* *}$ \\
\hline & $(0.036)$ & $(0.091)$ & $(0.063)$ & $(0.042)$ \\
\hline Including Zs & YES & YES & YES & YES \\
\hline Observations & 38385 & 30736 & 32988 & 58384 \\
\hline \multicolumn{5}{|c|}{$\begin{array}{l}\text { The model is estimated by two stages least squares. The first stage regressors include a dummy for being aged } \\
720 \text { months and above, a quartic polynomial in age, and full interactions of the two. The outcome equation } \\
\text { includes a quartic polynomial in age, and full interactions with the dummy for being aged } 720 \text { months and } \\
\text { above. The Z variables include year and district fixed effects, the individual sex ratio, the local unemployment } \\
\text { rate a year before, education dummies, number of children still living at home. } \\
\text { Note: } * * * \text { denotes statistical significance at the } 1 \% \text { level; ** at the } 5 \% \text { level and * at the } 10 \% \text { level. }\end{array}$} \\
\hline
\end{tabular}


Table 14. Results of estimation by respondent's education level.

\begin{tabular}{|c|c|c|c|}
\hline \multirow[t]{2}{*}{ Men } & (1) & (2) & (3) \\
\hline & College & High School & $\begin{array}{l}\text { Less than high } \\
\text { school }\end{array}$ \\
\hline \multirow{4}{*}{$\begin{array}{l}\text { Mean retirement, age } 59 \text { to }<60 \\
\text { Age } 60 \text { and above coefficient }\end{array}$} & 0.310 & 0.516 & 0.525 \\
\hline & $0.088^{* *}$ & $0.248 * * *$ & $0.255^{* * *}$ \\
\hline & $(0.030)$ & $(0.017)$ & $(0.013)$ \\
\hline & IV & \multicolumn{2}{|c|}{ Outcome variable: divorce rate } \\
\hline Mean divorce, age 59 to $<60$ & 0.070 & 0.051 & 0.048 \\
\hline \multirow[t]{2}{*}{ Retirement coefficient } & -0.114 & 0.039 & 0.012 \\
\hline & $(0.196)$ & $(0.037)$ & $(0.025)$ \\
\hline Including Zs & YES & YES & YES \\
\hline Observations & 25200 & 61563 & 115843 \\
\hline \multirow[t]{3}{*}{ Women } & (4) & (5) & (6) \\
\hline & College & High School & $\begin{array}{l}\text { Less than high } \\
\text { school }\end{array}$ \\
\hline & IV & \multicolumn{2}{|c|}{ First stage equation for retirement } \\
\hline Mean retirement, age 59 to $<60$ & 0.421 & 0.468 & 0.372 \\
\hline \multirow[t]{3}{*}{ Age 60 and above coefficient } & $0.130 * * *$ & $0.268^{* * *}$ & $0.329 * * *$ \\
\hline & $(0.037)$ & $(0.024)$ & $(0.015)$ \\
\hline & IV & \multicolumn{2}{|c|}{ Outcome variable: divorce rate } \\
\hline Mean divorce, age 59 to $<60$ & 0.107 & 0.105 & 0.080 \\
\hline \multirow[t]{2}{*}{ Retirement coefficient } & 0.200 & $-0.136^{* *}$ & -0.001 \\
\hline & $(0.212)$ & $(0.061)$ & $(0.027)$ \\
\hline Including Zs & YES & YES & YES \\
\hline Observations & 17830 & 37816 & 110261 \\
\hline \multicolumn{4}{|c|}{$\begin{array}{l}\text { The model is estimated by two stages least squares. The first stage regressors include a dummy for } \\
\text { being aged } 720 \text { months and above, a quadratic polynomial in age, and full interactions of the two. } \\
\text { The outcome equation includes a quadratic polynomial in age, and full interactions with the } \\
\text { dummy for being aged } 720 \text { months and above. The } Z \text { variables include yar and local area fixed } \\
\text { effects, the individual sex ratio, the local unemployment rate a year before, education dummies, } \\
\text { number of children still living at home. } \\
\text { Note: *** denotes statistical significance at the } 1 \% \text { level; ** at the } 5 \% \text { level and * at the } 10 \% \text { level. }\end{array}$} \\
\hline
\end{tabular}


Table 15. Results of estimation: other marital-status outcomes by father's occupation.

\begin{tabular}{|c|c|c|c|c|c|}
\hline MEN & $\begin{array}{l}\text { Fathers' } \\
\text { farmer } \\
\text { IV }\end{array}$ & $\begin{array}{l}\text { Fathers' top } \\
\text { occupations } \\
\text { Outcome varia } \\
\text { rate }\end{array}$ & $\begin{array}{l}\text { Father's } \\
\text { White collar } \\
\text { ble: Marriage }\end{array}$ & $\begin{array}{l}\text { Father's Blue } \\
\text { collar }\end{array}$ & Sample \\
\hline Retirement & $\begin{array}{l}-0.066 \\
(0.054)\end{array}$ & $\begin{array}{l}0.011 \\
(0.086)\end{array}$ & $\begin{array}{l}-0.004 \\
(0.085)\end{array}$ & $\begin{array}{l}-0.021 \\
(0.057)\end{array}$ & $\begin{array}{l}-0.025 \\
(0.033)\end{array}$ \\
\hline $\begin{array}{l}\text { Observations } \\
\text { MEN }\end{array}$ & $\begin{array}{l}46121 \\
\text { IV }\end{array}$ & $\begin{array}{l}38820 \\
\text { Outcome varia } \\
\text { rate }\end{array}$ & $\begin{array}{l}38190 \\
\text { ble: widow }\end{array}$ & 71555 & 202606 \\
\hline Retirement & $\begin{array}{l}0.030 \\
(0.025)\end{array}$ & $\begin{array}{l}-0.020 \\
(0.041)\end{array}$ & $\begin{array}{l}0.011 \\
(0.040)\end{array}$ & $\begin{array}{l}-0.038 \\
(0.031)\end{array}$ & $\begin{array}{l}-0.003 \\
(0.011)\end{array}$ \\
\hline $\begin{array}{l}\text { Observations } \\
\text { MEN }\end{array}$ & $\begin{array}{l}46121 \\
\text { IV }\end{array}$ & $\begin{array}{l}38820 \\
\text { Outcome varia } \\
\text { rate }\end{array}$ & $\begin{array}{l}38190 \\
\text { ble: single }\end{array}$ & 71555 & 202606 \\
\hline Retirement & $\begin{array}{l}-0.023 \\
(0.040)\end{array}$ & $\begin{array}{l}0.004 \\
(0.047)\end{array}$ & $\begin{array}{l}0.070 \\
0.050)\end{array}$ & $\begin{array}{l}0.026 \\
(0.032)\end{array}$ & $\begin{array}{l}0.018 \\
(0.020)\end{array}$ \\
\hline $\begin{array}{l}\text { Observations } \\
\text { WOMEN }\end{array}$ & $\begin{array}{l}46121 \\
\text { IV }\end{array}$ & $\begin{array}{l}38820 \\
\text { Outcome varia } \\
\text { rate }\end{array}$ & $\begin{array}{l}38190 \\
\text { ble: Marriage }\end{array}$ & 71555 & 202606 \\
\hline Retirement & $\begin{array}{l}-0.109 \\
(0.071)\end{array}$ & $\begin{array}{l}0.085 \\
(0.134)\end{array}$ & $\begin{array}{l}-0.015 \\
(0.091)\end{array}$ & $\begin{array}{l}0.070 \\
(0.069)\end{array}$ & $\begin{array}{l}-0.011 \\
(0.041)\end{array}$ \\
\hline $\begin{array}{l}\text { Observations } \\
\text { WOMEN }\end{array}$ & $\begin{array}{l}38385 \\
\text { IV }\end{array}$ & $\begin{array}{l}30736 \\
\text { Outcome varia } \\
\text { rate }\end{array}$ & $\begin{array}{l}32988 \\
\text { ble: widow }\end{array}$ & 58384 & 165907 \\
\hline Retirement & $\begin{array}{l}0.067 \\
(0.058)\end{array}$ & $\begin{array}{l}-0.078 \\
(0.092)\end{array}$ & $\begin{array}{l}0.054 \\
(0.066)\end{array}$ & $\begin{array}{l}0.028 \\
(0.057)\end{array}$ & $\begin{array}{l}0.032 \\
(0.032)\end{array}$ \\
\hline $\begin{array}{l}\text { Observations } \\
\text { WOMEN }\end{array}$ & $\begin{array}{l}38385 \\
\text { IV }\end{array}$ & $\begin{array}{l}30736 \\
\text { Outcome varia } \\
\text { rate }\end{array}$ & $\begin{array}{l}32988 \\
\text { ble: single }\end{array}$ & 58384 & 165907 \\
\hline Retirement & $\begin{array}{l}-0.018 \\
(0.034)\end{array}$ & $\begin{array}{l}0.080 \\
(0.085)\end{array}$ & $\begin{array}{l}-0.008 \\
(0.048)\end{array}$ & $\begin{array}{l}-0.0008 \\
(0.030)\end{array}$ & $\begin{array}{l}0.007 \\
(0.021)\end{array}$ \\
\hline Observations & 38385 & 30736 & 32988 & 58384 & 165907 \\
\hline
\end{tabular}


Table 16 A. Full Results of Estimation (See Tables 10 and 11, Specification 2).

\begin{tabular}{|c|c|c|c|c|c|c|}
\hline & Men, Father Far & & & Women, Fathe & Farmer & \\
\hline & IV first stage & IV outcome & OLS & IV First Stage & IV Outcome & OLS \\
\hline & Retirement & Divorce & Divorce & Retirement & Divorce & Divorce \\
\hline D Age $>=60$ & $0.297 * * *$ & & & $0.323 * * *$ & & \\
\hline & $(0.0206)$ & & & (0.0245) & & \\
\hline Retired & & $0.0494 *$ & $0.00645 * *$ & & $0.0676^{*}$ & -0.00218 \\
\hline & & $(0.0270)$ & (0.00299) & & $(0.0356)$ & $(0.00365)$ \\
\hline local U Rate & $-0.00522 * *$ & $0.00557 * * *$ & $0.00534 * * *$ & 0.00220 & 0.00213 & 0.00228 \\
\hline & $(0.00237)$ & $(0.00146)$ & $(0.00146)$ & $(0.00273)$ & $(0.00208)$ & $(0.00207)$ \\
\hline sex-ratio & -0.0651 & -0.0485 & -0.0470 & 0.0515 & -0.0332 & -0.0320 \\
\hline & $(0.190)$ & $(0.121)$ & $(0.120)$ & $(0.216)$ & $(0.156)$ & $(0.155)$ \\
\hline children at home & $-0.0129 * * *$ & $-0.0145 * * *$ & $-0.0151 * * *$ & $-0.0216^{* * *}$ & $-0.00690 * * *$ & $-0.00842 * * *$ \\
\hline & $(0.00147)$ & $(0.000770)$ & $(0.000687)$ & $(0.00226)$ & $(0.00194)$ & $(0.00180)$ \\
\hline junior college & $0.101 * * *$ & -0.0136 & -0.00940 & $0.124 * * *$ & 0.00340 & 0.0119 \\
\hline & $(0.0144)$ & $(0.0109)$ & $(0.0106)$ & $(0.0154)$ & $(0.0151)$ & $(0.0144)$ \\
\hline high school & $0.0898 * * *$ & -0.00708 & -0.00339 & $0.0879 * * *$ & 0.00768 & 0.0136 \\
\hline & $(0.0115)$ & $(0.00912)$ & $(0.00877)$ & $(0.0145)$ & $(0.0145)$ & $(0.0142)$ \\
\hline middle tech & $0.0911 * * *$ & $-0.0172 * *$ & $-0.0134^{*}$ & 0.0153 & -0.00723 & -0.00642 \\
\hline & $(0.00958)$ & $(0.00764)$ & $(0.00723)$ & $(0.0123)$ & $(0.0128)$ & $(0.0128)$ \\
\hline middle school & $0.111 * * *$ & $-0.0205^{* *}$ & $-0.0159^{*}$ & $0.0476^{* * *}$ & 0.00832 & 0.0115 \\
\hline & $(0.0123)$ & $(0.00932)$ & $(0.00880)$ & $(0.0132)$ & $(0.0135)$ & $(0.0135)$ \\
\hline < middle school & $0.114 * * *$ & $-0.0257 * * *$ & $-0.0209 * * *$ & $0.0209^{*}$ & -0.0118 & -0.0106 \\
\hline & $(0.00933)$ & $(0.00754)$ & $(0.00688)$ & $(0.0117)$ & $(0.0123)$ & $(0.0123)$ \\
\hline (1-D)*Age & $0.0583 * * *$ & -0.00235 & & 0.0269 & -0.0169 & \\
\hline & $(0.0205)$ & $(0.00872)$ & & $(0.0228)$ & $(0.0131)$ & \\
\hline (1-D)*Age2 & $-0.0172 * *$ & 0.00293 & & $-0.0141^{*}$ & -0.00278 & \\
\hline & $(0.00751)$ & $(0.00314)$ & & $(0.00834)$ & $(0.00498)$ & \\
\hline (1-D)*Age3 & $-0.00355^{* * *}$ & 0.000499 & & $-0.00232 * *$ & -0.000213 & \\
\hline & $(0.00104)$ & $(0.000486)$ & & $(0.00115)$ & $(0.000768)$ & \\
\hline (1-D)*Age4 & $-0.000169 * * *$ & $2.44 \mathrm{e}-05$ & & $-9.55 e-05 *$ & $-2.93 e-06$ & \\
\hline & $(4.79 \mathrm{e}-05)$ & $(2.49 \mathrm{e}-05)$ & & $(5.30 \mathrm{e}-05)$ & $(3.92 \mathrm{e}-05)$ & \\
\hline D*Age & $0.112 * * *$ & -0.0159 & & $0.130 * * *$ & -0.0194 & \\
\hline & (0.0149) & $(0.0100)$ & & $(0.0188)$ & $(0.0132)$ & \\
\hline D*Age2 & $-0.0293 * * *$ & 0.00462 & & $-0.0315^{* * *}$ & 0.00412 & \\
\hline & $(0.00541)$ & $(0.00356)$ & & $(0.00678)$ & $(0.00448)$ & \\
\hline D*Age3 & $0.00353 * * *$ & -0.000622 & & $0.00411^{* * *}$ & -0.000445 & \\
\hline & $(0.000748)$ & $(0.000503)$ & & $(0.000927)$ & $(0.000627)$ & \\
\hline D*Age4 & $-0.000153^{* * *}$ & $2.89 \mathrm{e}-05$ & & $-0.000196^{* * *}$ & $1.72 \mathrm{e}-05$ & \\
\hline & $(3.47 \mathrm{e}-05)$ & $(2.41 \mathrm{e}-05)$ & & $(4.26 \mathrm{e}-05)$ & $(2.98 \mathrm{e}-05)$ & \\
\hline Age & & & $-0.00225^{* * *}$ & & & $-0.00164 * *$ \\
\hline & & & $(0.000577)$ & & & $(0.000713)$ \\
\hline Age2 & & & $0.000165 *$ & & & $-8.32 \mathrm{e}-05$ \\
\hline & & & $(9.84 \mathrm{e}-05)$ & & & $(0.000127)$ \\
\hline Age3 & & & $-4.44 \mathrm{e}-06$ & & & $-1.26 \mathrm{e}-05$ \\
\hline & & & $(6.07 e-06)$ & & & $(7.93 e-06)$ \\
\hline Age4 & & & $-6.42 e-07$ & & & $1.62 \mathrm{e}-06$ \\
\hline & & & $(1.11 \mathrm{e}-06)$ & & & $(1.43 \mathrm{e}-06)$ \\
\hline Observations & 46,121 & 46,121 & 46,121 & 38,385 & 38,385 & 38,385 \\
\hline Rsquared & 0.696 & 0.019 & 0.023 & 0.667 & 0.016 & 0.025 \\
\hline
\end{tabular}


Table 16B. Full Results of Estimation (See Tables 8 and 9, Specification 2).

\begin{tabular}{|c|c|c|c|c|c|c|}
\hline & Men Sample & & & Women Sampl & & \\
\hline & IV first stage & $\begin{array}{l}\text { IV } \\
\text { Outcome }\end{array}$ & OLS & IV First Stage & IV Outcome & OLS \\
\hline & Retirement & Divorce & Divorce & Retirement & Divorce & Divorce \\
\hline D Age $>=60$ & $0.235^{* * *}$ & & & $0.293 * * *$ & & \\
\hline & $(0.00981)$ & & & $(0.0119)$ & & \\
\hline Retired & & 0.0140 & 0.00267 & & -0.0178 & $-0.0297 * * *$ \\
\hline & & $(0.0215)$ & $(0.00181)$ & & $(0.0257)$ & $(0.00247)$ \\
\hline local U Rate & $-0.00301 * * *$ & $0.00249 * * *$ & $0.00246^{* * *}$ & 0.000760 & $0.00469 * * *$ & $0.00468 * * *$ \\
\hline & $(0.00114)$ & $(0.000877)$ & $(0.000875)$ & $(0.00125)$ & $(0.00126)$ & $(0.00126)$ \\
\hline sex-ratio & 0.0708 & $-0.219 * * *$ & $-0.216^{* * *}$ & -0.0175 & 0.0208 & 0.0286 \\
\hline & $(0.0953)$ & $(0.0742)$ & $(0.0740)$ & $(0.105)$ & $(0.102)$ & $(0.101)$ \\
\hline children at home & $-0.0167 * * *$ & $-0.0228 * * *$ & $-0.0229 * * *$ & $-0.0154 * * *$ & $-0.0113 * * *$ & $-0.0115^{* * *}$ \\
\hline & $(0.000753)$ & $(0.000596)$ & $(0.000480)$ & $(0.00118)$ & $(0.00132)$ & $(0.00126)$ \\
\hline junior college & $0.0943 * * *$ & $0.00723 *$ & $0.00832 * *$ & $0.0983 * * *$ & 0.00267 & 0.00383 \\
\hline & $(0.00420)$ & $(0.00412)$ & $(0.00361)$ & $(0.00474)$ & $(0.00582)$ & $(0.00525)$ \\
\hline high school & $0.103 * * *$ & $0.00725^{* *}$ & $0.00841 * * *$ & $0.0705 * * *$ & -0.00290 & -0.00192 \\
\hline & $(0.00340)$ & $\begin{array}{c}(0.00355) \\
-\end{array}$ & $(0.00282)$ & $(0.00447)$ & $(0.00535)$ & $(0.00502)$ \\
\hline middle tech & $0.125^{* * *}$ & $0.00958 * * *$ & $-0.00814^{* * *}$ & $0.0569^{* * *}$ & $-0.0225 * * *$ & $-0.0216^{* * *}$ \\
\hline & $(0.00279)$ & $(0.00346)$ & $(0.00223)$ & $(0.00390)$ & $(0.00471)$ & $(0.00446)$ \\
\hline middle school & $0.134 * * *$ & -0.00279 & -0.00124 & $0.0585 * * *$ & $-0.0135 * * *$ & $-0.0126^{* * *}$ \\
\hline & $(0.00379)$ & $(0.00420)$ & $(0.00309)$ & $(0.00432)$ & $(0.00506)$ & $(0.00482)$ \\
\hline$<$ middle school & $0.131 * * *$ & $-0.0106^{* * *}$ & $-0.00913 * * *$ & $0.0419 * * *$ & $-0.0317 * * *$ & $-0.0309 * * *$ \\
\hline & $(0.00268)$ & $(0.00346)$ & $(0.00206)$ & $(0.00370)$ & $(0.00435)$ & $(0.00420)$ \\
\hline (1-D)*Age & $0.0513 * * *$ & 0.00167 & & $0.0354 * * *$ & 0.00924 & \\
\hline & $(0.00973)$ & $(0.00595)$ & & $(0.0113)$ & $(0.00869)$ & \\
\hline (1-D)*Age2 & $-0.0253 * * *$ & $0.00337 *$ & & $-0.0186 * * *$ & 0.00499 & \\
\hline & $(0.00357)$ & $(0.00189)$ & & $(0.00411)$ & $(0.00304)$ & \\
\hline (1-D)*Age3 & $-0.00488 * * *$ & 0.000461 & & $-0.00327 * * *$ & 0.000651 & \\
\hline & $(0.000492)$ & $(0.000287)$ & & $(0.000563)$ & $(0.000458)$ & \\
\hline (1-D)*Age4 & $-0.00023 * * *$ & $1.92 \mathrm{e}-05$ & & $-0.000145^{* * *}$ & $2.92 \mathrm{e}-05$ & \\
\hline & $(2.27 \mathrm{e}-05)$ & $(1.45 \mathrm{e}-05)$ & & $(2.58 \mathrm{e}-05)$ & $(2.30 \mathrm{e}-05)$ & \\
\hline D*Age & $0.108 * * *$ & -0.00568 & & $0.109 * * *$ & 0.00193 & \\
\hline & $(0.00712)$ & $(0.00622)$ & & $(0.00879)$ & $(0.00822)$ & \\
\hline D*Age2 & $-0.0280 * * *$ & -0.000271 & & $-0.0250 * * *$ & -0.00281 & \\
\hline & $(0.00261)$ & $(0.00219)$ & & $(0.00316)$ & $(0.00281)$ & \\
\hline D*Age3 & $0.00344^{* * *}$ & 0.000158 & & $0.00315^{* * *}$ & 0.000438 & \\
\hline & $(0.000363)$ & $(0.000310)$ & & $(0.000433)$ & $(0.000397)$ & \\
\hline D*Age4 & $-0.00015^{* * *}$ & $-1.13 e-05$ & & $-0.000148 * * *$ & $-2.11 \mathrm{e}-05$ & \\
\hline & $(1.69 \mathrm{e}-05)$ & $(1.49 \mathrm{e}-05)$ & & $(1.99 \mathrm{e}-05)$ & $(1.90 \mathrm{e}-05)$ & \\
\hline Age & & & $-0.00418^{* * *}$ & & & $-0.0015 * * *$ \\
\hline & & & $(0.000326)$ & & & $(0.000455)$ \\
\hline Age2 & & & $0.000264 * * *$ & & & $-1.30 \mathrm{e}-05$ \\
\hline & & & $(5.96 \mathrm{e}-05)$ & & & $(8.26 \mathrm{e}-05)$ \\
\hline Age3 & & & $2.99 \mathrm{e}-06$ & & & $-2.07 e-05 * * *$ \\
\hline & & & $(3.45 \mathrm{e}-06)$ & & & $(4.86 \mathrm{e}-06)$ \\
\hline Age4 & & & $-1.83 \mathrm{e}-06^{* * *}$ & & & $1.07 \mathrm{e}-06$ \\
\hline & & & $(6.55 e-07)$ & & & $(9.06 e-07)$ \\
\hline Observations & 202,606 & 202,606 & 202,606 & 165,907 & 165,907 & 165,907 \\
\hline Rsquared & 0.680 & 0.020 & 0.020 & 0.679 & 0.030 & 0.030 \\
\hline
\end{tabular}




\section{Appendix Table A.}

\begin{tabular}{|c|c|c|c|c|}
\hline & Father Farmer \% & $\begin{array}{l}\text { Father Unskilled } \\
\text { worker \% }\end{array}$ & $\begin{array}{l}\text { Father Rural } \\
\text { worker \% }\end{array}$ & $\begin{array}{l}\text { Observations } \\
\text { per district }\end{array}$ \\
\hline Ain & 23.18 & 1.56 & 12.35 & 10414 \\
\hline Aisne & 12.76 & 16.0 & 11.46 & 14409 \\
\hline Allier & 25.70 & 13.47 & 6.70 & 14563 \\
\hline Alpes-de-Haute-Provence & 21.30 & 8.37 & 3.86 & 2976 \\
\hline Hautes-Alpes & 24.06 & 8.48 & 1.99 & 2664 \\
\hline Alpes-Maritimes & 8.35 & 7.05 & 3.44 & 23028 \\
\hline Ardèche & 29.14 & 10.29 & 2.09 & 5463 \\
\hline Ardennes & 13.52 & 20.62 & 4.12 & 10284 \\
\hline Ariège & 26.87 & 15.45 & 5.50 & 3398 \\
\hline Aube & 17.58 & 15.51 & 5.60 & 10731 \\
\hline Aude & 16.62 & 8.62 & 18.64 & 7346 \\
\hline Aveyron & 41.79 & 10.59 & 2.58 & 6363 \\
\hline Bouches-du-Rhône & 7.39 & 9.88 & 3.82 & 40183 \\
\hline Calvados & 15.58 & 14.23 & 7.81 & 20918 \\
\hline Cantal & 35.99 & 10.70 & 9.10 & 6933 \\
\hline Charente & 26.33 & 12.40 & 11.37 & 11609 \\
\hline Charente-Maritime & 25.90 & 8.71 & 6.38 & 16603 \\
\hline Cher & 16.33 & 18.59 & 6.59 & 9135 \\
\hline Corrèze & 30.56 & 10.49 & 3.37 & 15138 \\
\hline Corse & 25.29 & 5.46 & 6.76 & 1639 \\
\hline Côte-d'Or & 15.98 & 11.83 & 4.95 & 14458 \\
\hline Côtes-d'Armor & 37.44 & 7.71 & 4.21 & 13715 \\
\hline Creuse & 40.33 & 6.54 & 5.84 & 8147 \\
\hline Dordogne & 35.43 & 10.09 & 8.03 & 8807 \\
\hline Doubs & 19.43 & 16.19 & 1.77 & 20808 \\
\hline Drôme & 26.96 & 11.25 & 3.51 & 9299 \\
\hline Eure & 13.89 & 15.29 & 8.68 & 16533 \\
\hline Eure-et-Loir & 19.89 & 14.84 & 8.36 & 7857 \\
\hline Finistère & 28.46 & 6.81 & 6.78 & 25967 \\
\hline Gard & 13.99 & 12.67 & 8.90 & 13848 \\
\hline Haute-Garonne & 15.80 & 8.55 & 3.88 & 22842 \\
\hline Gers & 37.72 & 6.76 & 11.25 & 4409 \\
\hline Gironde & 11.41 & 9.58 & 8.77 & 30758 \\
\hline Hérault & 12.83 & 7.69 & 10.48 & 24697 \\
\hline Ille-et-Vilaine & 30.34 & 8.29 & 3.90 & 21035 \\
\hline Indre & 24.53 & 12.12 & 9.54 & 6813 \\
\hline Indre-et-Loire & 20.16 & 11.89 & 6.26 & 14595 \\
\hline Isère & 14.64 & 15.93 & 2.16 & 22513 \\
\hline Jura & 26.41 & 13.40 & 1.99 & 13094 \\
\hline Landes & 27.16 & 10.00 & 4.91 & 6803 \\
\hline Loir-et-Cher & 28.43 & 13.15 & 8.96 & 5903 \\
\hline Loire & 20.09 & 18.13 & 1.70 & 18209 \\
\hline Haute-Loire & 39.66 & 10.51 & 0.85 & 5661 \\
\hline Loire-Atlantique & 21.10 & 9.00 & 2.83 & 25588 \\
\hline Loiret & 18.72 & 11.39 & 5.54 & 13986 \\
\hline Lot & 42.30 & 9.07 & 3.90 & 2922 \\
\hline Lot-et-Garonne & 37.00 & 9.15 & 7.16 & 6351 \\
\hline Lozère & 37.01 & 7.26 & 2.24 & 2988 \\
\hline Maine-et-Loire & 27.98 & 11.56 & 6.58 & 17253 \\
\hline Manche & 34.96 & 8.24 & 6.47 & 18181 \\
\hline Marne & 14.15 & 11.25 & 7.41 & 17345 \\
\hline Haute-Marne & 22.34 & 15.45 & 4.29 & 7484 \\
\hline Mayenne & 37.54 & 11.41 & 6.35 & 6742 \\
\hline Meurthe-et-Moselle & 8.89 & 18.42 & 2.08 & 16697 \\
\hline Meuse & 22.44 & 16.55 & 3.54 & 5705 \\
\hline Morbihan & 34.22 & 7.71 & 4.57 & 15239 \\
\hline
\end{tabular}




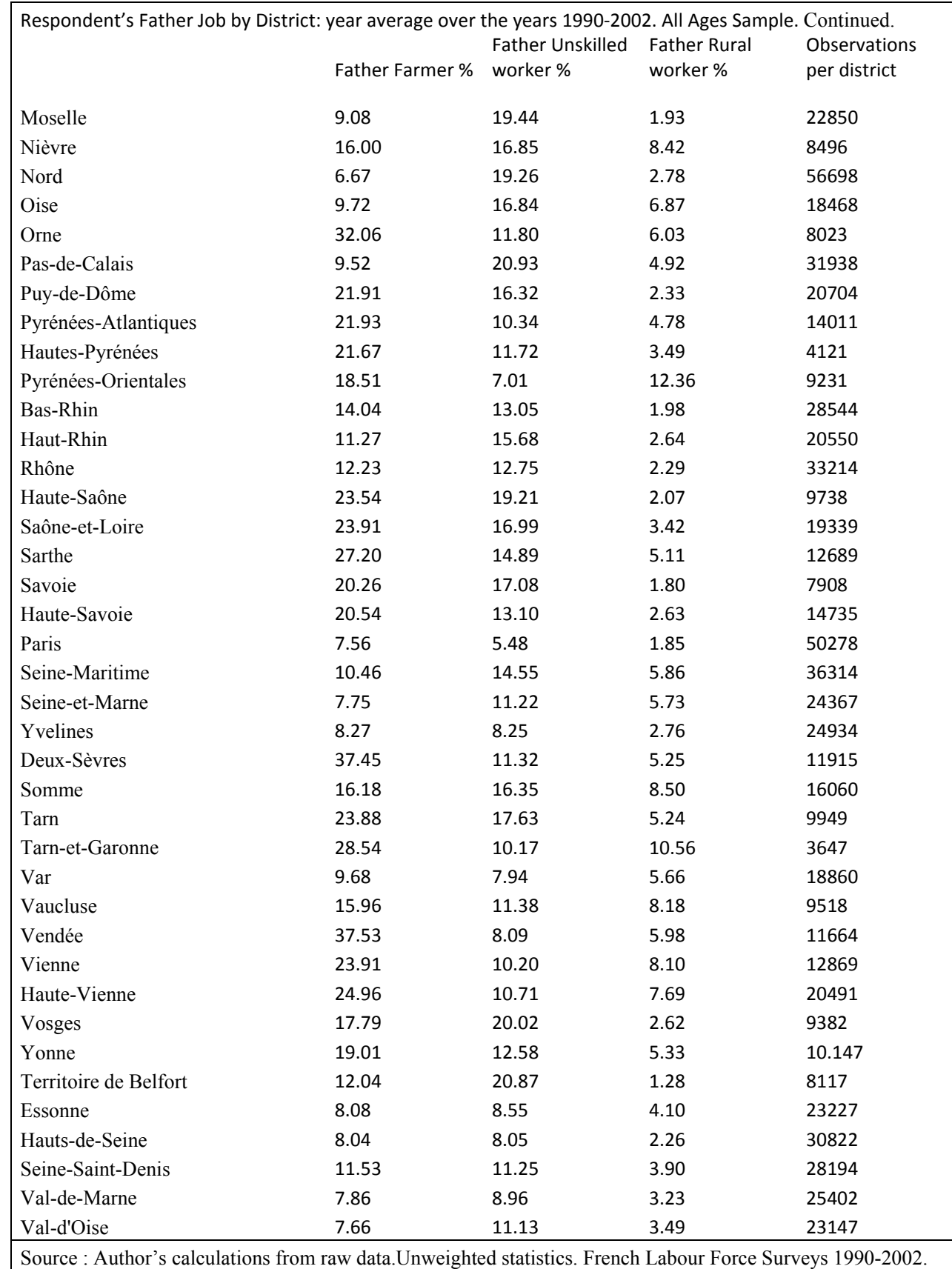




\section{Appendix. Original father's job classification in French.}

Catégorie socio-professionnelle du père

: sans objet ou non déclaré

10 : agriculteurs exploitants $23.71 \%$ of the sample

21 : artisans

22 : commerçants et assimilés

23 : chefs d'entreprise de 10 salariés ou plus

31 : professions libérales

33 : cadres de la fonction publique

34 : professeurs, professions scientifiques

35 : professions de l'information, des arts et des spectacles

37 : cadres administratifs et commerçiaux d'entreprises

38 : ingénieurs et cadres techniques d'entreprises

42 : instituteurs et assimilés

43 : professions intermédiaires de la santé et du travail social

44 : clergé, religieux

45 : professions intermédiaires administratives de la fonction publique

46 : professions intermédiaires administratives et commerciales

des entreprises

47 : techniciens

48 : contremaîtres, agents de maîtrise

52 : employés civils et agents de service de la fonction publique

53 : policiers et militaires

54 : employés administratifs d'entreprises

55 : employés de commerce

56 : personnels des services directs aux particuliers

62 : ouvriers qualifiés de type industriel

63 : ouvriers qualifiés de type artisanal

64 : chauffeurs

65 : ouvriers qualifiés de la manutention, du magasinage et du transport

67 : ouvriers non qualifiés de type industriel $11.66 \%$ of the sample

68 : ouvriers non qualifiés de type artisanal

69 : ouvriers agricoles $6.39 \%$ of the sample 